\title{
Public DeBt in DEVELOPING COUNTRIES: HAS THE MARKET-BASED MODEL WORKED?
}

\author{
Indermit Gill and Brian Pinto
}

\begin{abstract}
Over the past 25 years, significant levels of public debt and external finance are more likely to have enhanced macroeconomic vulnerability than economic growth in developing countries. This conclusion applies not just to countries with a history of high inflation and past default, but also to those in East Asia, with a long tradition of prudent macroeconomic policies and rapid growth. We examine why with the help of a conceptual framework drawn from the growth, capital flows and crisis literature for developing countries with access to the international capital markets ('market access countries' or MACs). We find that, while the chances of another generalized debt crisis have receded since the turbulence of the late 1990s, sovereign debt is indeed constraining growth in MACs, especially those with debt sustainability problems. Several prominent MACs have sought to address the debt and external finance problem by generating large primary fiscal surpluses, switching to flexible exchange rates and reforming fiscal and financial institutions. Such country-led initiatives completely dominate attempts to overhaul the international financial architecture or launch new lending instruments, which have so far met with little success. While the initial results of the countries' initiatives have been encouraging, serious questions remain about the viability of the model of market-based external development finance. Beyond crisis resolution, which has received attention in the form of the proposed sovereign debt restructuring mechanism, the international financial institutions may need to ramp up their role as providers of stable long-run development finance to MACs instead of exiting from them.
\end{abstract}

World Bank Policy Research Working Paper 3674, August 2005

The Policy Research Working Paper Series disseminates the findings of work in progress to encourage the exchange of ideas about development issues. An objective of the series is to get the findings out quickly, even if the presentations are less than fully polished. The papers carry the names of the authors and should be cited accordingly. The findings, interpretations, and conclusions expressed in this paper are entirely those of the authors. They do not necessarily represent the view of the World Bank, its Executive Directors, or the countries they represent. Policy Research Working Papers are available online at http://econ.worldbank.org.

Both authors are at the World Bank. This paper is drawn from a larger work program on sovereign debt and development in the Economic Policy and Debt Department, Poverty Reduction and Economic Management Anchor, of the World Bank. An abridged version will be appearing in a volume dedicated to an April 2005 conference on "The Financial Sector Post-Crisis: Challenges and Vulnerabilities”, organized jointly by the World Bank and The Brookings Institution. We thank Joshua Aizenman, Amar Bhattacharya, Nina Budina, Craig Burnside, Christophe Chamley, Ajay Chhibber, Gautam Datta, Norbert Fiess, Jim Hanson, Olivier Jeanne, Himmat Kalsi, Homi Kharas, Gobind Nankani, Vikram Nehru, Anand Rajaram, Luis Serven, John Williamson, Holger Wolf, and many others for useful comments or contributions. 


\section{INTRODUCTION}

Sovereign debt can help developing countries. It enables their governments to facilitate growth take-offs by investing in a critical mass of infrastructure projects and in the social sectors when taxation capacity is limited, or when the alternative would be to print money and compromise macroeconomic stability. ${ }^{1}$ Debt also facilitates tax smoothing and counter-cyclical fiscal policies, essential for reducing output volatility; and it permits an equitable alignment of benefits and costs for long-gestation projects by shifting taxation away from current generations.

This is what theory tells us. And there is every reason to believe that governments which borrow and spend prudently will reap these benefits in practice. But we also know that in practice, there has been a profusion of costly macroeconomic crises during the 1990s with public debt either being a central cause, e.g., Russia 1998 and Argentina 2001, or else absorbing the brunt of the impact, e.g., Indonesia, Korea, Malaysia, and Thailand during 1997-98. And the external debt crisis of the 1980s and the now-controversial financial liberalization of the early 1990s have raised serious questions about the benefits of market-based external finance for developing countries with access to the international capital markets, called 'market access countries' or MACs. These are the countries we look at in this paper (see Annex Table A).

In the face of mounting evidence that access to the international capital markets and rising public debt are more likely to have enhanced vulnerability than growth, we take a closer look at public debt in MACs and attempt to answer three questions:

- What are the chances of a generalized debt crisis as in the 1980s?

- Is public debt constraining economic growth?

- What should be done about public debt in developing countries?

Governments borrow in principle to finance public goods that increase welfare and promote growth. The spending has to be financed by taxation, through seignorage, or with debt. As Box 1 explains, there are circumstances in which sovereign debt makes sense. The optimal debt literature treats debt and taxes as intertemporal substitutes with Ponzi games ruled out. ${ }^{2}$ This is done by constraining the present value of debt to be less than that of taxes, which excludes unsustainable debt paths and crises. The optimality of debt is derived from that of taxation. ${ }^{3}$ Where taxes are nondistortionary (viz., do not alter the incentives embedded in relative prices) and satisfy Ricardian equivalence (viz., only the present value of taxes matters), the level and path of debt are indeterminate. When taxes are distorting (viz., change incentives and involve collection and enforcement costs), the path of taxes and hence that of debt matters. In this case, tax rates may have to be smoothed to minimize deadweight losses, and debt is a balancing item subject to the present value constraint mentioned above. If there is uncertainty, then tax rates may have to be smoothed over different states of nature, and debt with state-contingent payoffs may be needed.

\footnotetext{
${ }^{1}$ We don't know exactly how growth takeoffs occur; but it is reasonable to believe that a minimum amount of infrastructure and human capital would be necessary.

${ }^{2}$ An example of a Ponzi game is a government running primary deficits and rolling over debt while real interest rates exceed growth rates, so that the debt-to-GDP ratio grows without bound. This is unsustainable and will eventually result either in a burst of inflation - the unpleasant monetarist arithmetic of Sargent and Wallace (1981)—or default.

${ }^{3}$ This is the approach in Barro $(1976,1995)$.
} 
Growth seldom enters the picture explicitly; indeed, most theoretical models do not include a direct link between government debt and growth. Long-run growth is typically taken as exogenous and, with insolvency ruled out, the problem becomes one of allocating taxes over time to minimize deadweight losses from taxation given initial debt. However, unsustainable debt levels can lower growth by raising real interest rates and crowding out the private sector. And sovereign debt can facilitate the achievement of growth, for example, by enabling the optimal social provision of public goods such as education and infrastructure when taxation capacity is limited today but expected to be higher in the future. It also helps when public investments spur private investment through complementarities. But this critically assumes that only those public projects with economic returns exceeding the cost of borrowing are selected; and that the government subsidizes such projects when their financial return is lower than the cost of funds through redistributive taxation (as opposed to further borrowing): in other words, that governments play their assigned role.

\section{Box 1. Why Governments Borrow}

A government can finance its spending and development efforts by borrowing, by taxing output, or by printing money (the so-called "inflation tax" or seignorage) $)^{1 /}$. Three reasons explain why public debt may be better than taxation:

Tilting: Allowing a more equitable manner in which country can exploit investment opportunities with long gestation periods. In a growing economy, it would be inequitable to tax current (poorer) generations to pay for investments that will benefit future (richer) generations.

Smoothing: Allowing a more efficient manner for conducting counter-cyclical policies or meeting emergency spending needs. Raising and lowering taxes frequently may entail efficiency losses and generate economic uncertainty.

Stability: Excessive reliance on printing money could lead to high and volatile inflation, which obscures the information content of relative prices and hurts investment.

But debt has eventually to be repaid-borrowing is simply postponed taxation. Hence, the use to which funds are put and the returns relative to the cost of borrowing become crucial. Computing these returns is not easy. For example, if the government invests in infrastructure, the returns include not just the user fees but also higher future taxes if the infrastructure investments lead to faster growth.

1 / Printing money is not always inflationary, as in a growing economy where real income is rising.

The only explicit debt-growth theoretical link is that between external borrowing (public or private) and growth, the assumption being that if the marginal product of capital is higher than the world interest rate for developing countries, then such countries would benefit from external borrowing (Eaton (1993)). But even here, external debt helps to exploit the existing growth potential of the country; it does not enhance it. Theoretically, therefore, the only guideline one finds is that the rate of return on spending should exceed the marginal cost of borrowing on the assumption that debt is eventually repaid. ${ }^{4}$

A more recent debate stimulated by the growth slowdown in the European Monetary Union (EMU) focuses on the composition of government spending. Blanchard and Giavazzi (2003) argue that if the EMU's Stability and Growth Pact targets of a fiscal deficit of 3 percent of GDP and public debt of 60 percent of GDP are achieved by cutting public investment, this would reduce long-run growth and eventually lead to rising fiscal deficits and debt-as observed in key EMU countries. Their point is that the pact "puts no pressure on EMU members to reduce current government spending, so as to lower tax rates and make room for higher public investment”. In

\footnotetext{
${ }^{4}$ The economic rate of return (ROR) on some types of public spending, e.g., on power plants, is easier to compute than on others, e.g., education — which is not to say that the economic ROR on power plants is easy to compute.
} 
this framework, taxes must eventually cover both government primary current spending (i.e., noninterest spending unrelated to public investments) and the subsidy on public investment needed for projects where the economic rate of return (ROR) exceeds the interest rate, but the financial ROR does not. In particular, the subsidy for such projects should not be financed by additional borrowing, which might put public debt on an unsustainable course. The implicit assumptions are that there is no waste in government current spending, that borrowing is only for worthwhile public investment projects (economic ROR exceeds the interest rate) and that any investment subsidy required (difference between the interest rate and the net financial ROR) comes strictly from taxation. Meeting these conditions is likely to require higher public saving. These ideas are applicable to the concept of 'fiscal space' that has been raised in the context of some MACs.

Table 1 lists the top ten MACs - India, China, Brazil, Mexico, Korea, Turkey, Indonesia, Russia, Argentina and Poland-in terms of public debt (external plus domestic). In 2002, their combined public debt was $\$ 2.2$ trillion or more than two-thirds of total MAC public debt. These countries also accounted for about $\$ 1.4$ trillion in external debt - that is, public plus private debt, held by external creditors. When public debt is expressed as a ratio of GDP, the top eleven MAC debtors in 2002 were Lebanon, Jamaica, Argentina, Uruguay, Jordan, Turkey, India, Pakistan, Morocco, the Philippines and Indonesia, with ratios ranging between 90 and 180 percent. ${ }^{5}$ All but three countries had higher public debt-to-GDP ratios than a decade earlier in 1992, the year by which the Brady Plan resolution of the 1980s debt crisis had been implemented for the major participating countries. In the three exceptions, Jamaica, Jordan and Morocco, the public debt-toGDP ratio was exceptionally high in 1992 and had come down only modestly by 2002.

Interestingly, of the 17 countries in Table 1, China was the only one not to experience a debt or balance-of-payments crisis during the 1980 s or later. ${ }^{6}$ The paper pays special attention to many of the countries listed in the table.

Table 1. Sovereign Debt-Big MACs and Debt Majors

\begin{tabular}{lcclcc}
\hline & \multicolumn{2}{c}{ Total Public Debt (\$ Billions) } & & \multicolumn{2}{c}{ Public Debt to GDP (\%) } \\
\hline & $\mathbf{1 9 9 2}$ & $\mathbf{2 0 0 2}$ & & $\mathbf{1 9 9 2}$ & $\mathbf{2 0 0 2}$ \\
India & 156 & 380 & Lebanon & 70 & 177 \\
China & 68 & 366 & Jamaica & 181 & 149 \\
Brazil & 165 & 284 & Argentina & 26 & 126 \\
México & 118 & 280 & Uruguay & 48 & 109 \\
Korea & 61 & $232^{1 /}$ & Jordan & 167 & 100 \\
Turkey & 65 & 173 & Turkey & 40 & 94 \\
Indonesia & 56 & 149 & India & 74 & 81 \\
Russia & 12 & 118 & Pakistan & 81 & 90 \\
Argentina & 59 & 117 & Morocco & 102 & 90 \\
Poland & 44 & 72 & Philippines & 81 & 89 \\
& & & Indonesia & 40 & 86 \\
\hline 1/Dan
\end{tabular}

1/Data for 2001.

Note: Public debt is defined to be public and publicly guaranteed external debt plus domestic public debt.

Source: Global Development Finance (World Bank), World Economic Outlook (IMF) and staff estimates.

\footnotetext{
${ }^{5}$ There are varying definitions of the numerator and the denominator across countries. Turkey's debt ratios are reported as a share of GNP, and Brazil and Turkey both report public debt net of central bank assets.

${ }^{6}$ Lebanon remains an enigma. In spite of being an outlier in its public debt-to-GDP ratio, it did not suffer a debt default or financial system crisis. But its exchange rate collapsed during 1986-87 and 1992 as a result of domestic credit-financed expansions in government spending which depleted reserves, akin to a first generation crisis (see Box 3 below). It also benefited from a pubic debt reprofiling under the auspices of the Paris II Conference held in November 2002 (“One-Year Progress After Paris II”, Special Report, Ministry of Finance, Republic of Lebanon, December 2003.)
} 
The next section presents a framework for examining sovereign debt and external finance from the perspective of vulnerability and growth. This is followed by a discussion of the main factors explaining episodes of either large and abrupt increases or decreases in the public debt-toGDP ratio in MACs. This feeds into answers to the three questions posed at the outset. The last section concludes and questions the viability of market-based development finance. 


\section{A CONCEPTUAL FRAMEWORK FOR DEBT AND DEVELOPMENT}

The analytical framework for MACs presented here surveys three strands of the economic literature: (i) neoclassical growth theory and its progeny, endogenous growth theory; (ii) an empirically-inspired literature on external capital flows; and (iii) an empirically-driven literature on macroeconomic crises. The survey leads to the following main findings:

- MACs have not proved adept at using sovereign debt, either because of weaknesses in the countries themselves or deficiencies in the market. With official finance shrinking as a share of the total, one has to ask if reliance on external market-based sources of finance constitutes a viable model of development.

- The crises of the 1980s and 1990s, even when day-to-day macroeconomic policies have been conservative as in many East Asian countries, have highlighted the importance of the government's intertemporal budget constraint. This is where the chickens come home to roost, even if their origin is in the private sector. Governments must be ready to play a shock-absorbing role, in part because of unanticipated shocks, in part because of missing insurance markets. This has a corollary: the government needs a strong balance sheet and debt headroom.

- Political economy factors explain much better why countries overborrow and end up in crises. It is difficult to think of pure economic reasons why crises occur.

Following the survey, we discuss conceptual links between public debt and growth, and alternative ways of interpreting MAC debt.

\subsection{Growth Theory, Capital Flows and Crises}

\section{Growth Theory: Neoclassical and Endogenous}

In neoclassical growth theory, e.g., the Solow-Swan model, the long-run growth rate is constant and is equal to the growth rate of the population or labor force under the assumptions of exogenously given technology, constant returns to scale and, critically, diminishing marginal returns to capital. In this framework, similar countries will converge to the same steady state marked by zero per capita growth - because all variables grow at the same rate as population. The challenge is to find and adhere to the so-called "golden rule" of capital accumulation, i.e., find that savings rate which maximizes per capita consumption across generations. ${ }^{7}$

An implication is that countries with lower capital per worker will grow faster and eventually converge to the same steady state as countries with higher capital per worker, the socalled "absolute convergence hypothesis". As rich countries tend to have higher capital per worker, and therefore a lower marginal product of capital under the neoclassical assumptions, freeing up capital movements will lead to a mutually beneficial movement of capital from rich to poor countries, facilitating convergence. This idea is expressed succinctly in Eichengreen and Mussa (1998).

"The classic case for international capital mobility is well-known but worth restating. Flows from capitalabundant to capital-scarce countries raise welfare in the sending and receiving countries alike on the assumption that the marginal product of capital is higher in the latter than in the former. Free capital movements thus permit a more efficient global allocation of savings and direct resources toward their most productive uses.”

\footnotetext{
${ }^{7}$ For a detailed discussion, see Barro and Sala-i-Martin (1995), chapter 1.
} 
Absolute convergence has not been supported by the data, leading to the notion of conditional convergence, that is, once the differences in steady-states across countries are controlled for, poorer countries will grow faster. Hence, one might still hold out hope that in a world of liberalized capital flows, capital would flow from rich to poor countries, augmenting their capital base and spurring growth. However, empirical evidence is to the contrary. Even though capital flows to middle income countries increased rapidly during the 1990s, “..from less than $\$ 40$ billion per year over the period 1983-1990 to an average of about $\$ 200$ billion a year” ${ }^{8}$ during the first half of the 1990s - the lion's share of capital flows are among rich countries, not from rich to developing countries. Developing countries' share in global private capital flows was just 12 percent in 1991, and fell to 8 percent by 2000 (see Figure 1). ${ }^{9}$

\section{Figure 1. Share of Developing Countries in Global Capital Flows}

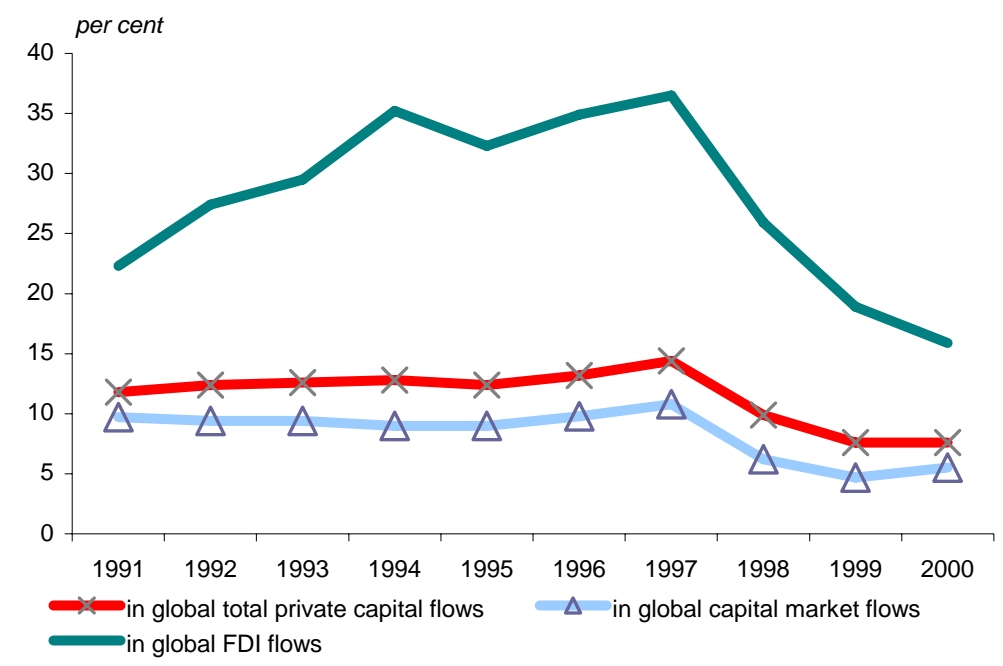

One explanation for this unexpected pattern of capital flows is that the assumed diminishing marginal returns to capital posited by neoclassical growth theory may not obtain in practice. This is the core idea of endogenous growth theory, namely, that technological progress may be linked to capital accumulation, and that human capital should also be included, both of which favor rich countries. The upshot is that the income gap between rich and poor countries may not narrow. This is a simplistic statement of a complex debate about economic growth. The point is that many factors, economic and non-economic, could intervene to lower returns to capital in poorer countries below those in richer ones, a theme that is pursued below.

\section{Higher Capital Flows: Enhanced Growth versus Enhanced Vulnerability}

The observation that rich-to-poor capital flows are minor compared to those among rich countries has spawned a number of explanations, which are summarized in Box 2. The explanations center on the idea that risk-adjusted returns in the poorer countries may actually be lower than those in the richer countries because of institutions, incentives and productivity.

\footnotetext{
${ }^{8}$ Keynote address by the General Manager of the Bank for International Settlements, Mr. Andrew Crockett, to the $33^{\text {rd }}$ Seacen Governors' Conference in Bali on 13/2/98.

${ }^{9}$ Global Development Finance (2001).
} 


\section{Box 2. Why Capital Flows Diverge From Their Predicted Direction and Volumes}

Theory says capital should flow from capital-abundant, rich countries to capital-scarce, poor countries. In practice, however, capital flows among rich countries dwarf those from rich to poor countries in volume. Why? Because of factors reducing risk-adjusted returns in poor countries, the default problem, and the limited range of instruments available in international financial markets.

- Risk-adjusted returns to capital in poor countries may be lower than in rich countries, contradicting the law of diminishing returns. Factors such as human capital, the quality of institutions and political and policy predictability may operate to lower returns and raise risks notwithstanding relative capital capital-scarcity. ${ }^{1 /}$ Practice highlights the key role of institutions, incentives and productivity.

- Default risk, and the difficulty of securing legal redress against both foreign private and especially sovereign borrowers for enforcement of property rights, might also explain the home bias in lending and portfolio allocations of rich countries.

- The virtual absence of debt instruments that would adjust payments to shocks stemming from the terms-of-trade or world interest rates might appear surprising in view of the high levels of sophistication in world financial markets today. GDP-indexed bonds do not as yet exist while currency risk is typically borne by the borrower. One impediment might be moral hazard stemming from the ability of sovereign borrowers to influence the indexation variable, although this can be overcome by appropriate choice of an exogenous variable. Yet such instruments do not exist.

1/ See, for example, Lucas (1988) and Mankiw, Romer and Weil (1992).

Source: Sturzenegger and Wolf (2004).

Moreover, even the spurt of capital flows into MACs following the Brady Plan resolution of the 1980s debt crisis, and subsequent widespread liberalization of capital markets during the 1990s, may not have boosted investment and growth. Using a sample of 60 developing countries, one study found that, while the growing financial integration with the rest of the world has increased access to foreign private capital, the relationship between foreign capital and domestic investment has weakened, reflecting changes in the composition of inflows, offsetting outflows, and increased foreign currency reserve requirements. ${ }^{10}$ Another study found that a substantial share of the surge in capital inflows has been channeled into reserve accumulation, and that an equal share found its way back out of the country. Using investment regressions, this study found that FDI shows the strongest link with aggregate investment, with a coefficient close to one. ${ }^{11}$

A third study fails to find persuasive evidence of a "growth bonus" associated with an increased share of foreign saving in financing the domestic capital stock in a wide range of developing countries. The evidence suggests the opposite: in a sample of 47 countries, those which relied more on national savings (a higher "self-financing ratio") grew much faster throughout the 1990s. ${ }^{12}$ This result persists even when the impact of the quality of institutions on growth is allowed for. These findings are consistent with the idea that financial integration may have facilitated diversification of assets and liabilities, but failed to offer net new sources of financing capital in developing countries. ${ }^{13}$

\footnotetext{
${ }^{10}$ Mody and Murshid (2002).

${ }^{11}$ Bosworth and Collins (1999).

${ }^{12}$ Aizenman, Pinto and Radziwill (2004). See also Aizenman (2005), which contains a comparison of Korea and Chile.

${ }^{13}$ Based on a regression of average per capita growth rates during the 1990s on the level, square and cube of the average self-financing ratio and its standard deviation.
} 
Two other recent, related studies are worth mentioning. One finds that moving from complete financial autarky to complete financial openness would augment consumption by about 1 percent per year or 10-20 percent of initial GDP depending upon the discount rate; the actual benefit would be smaller as most countries are not financially autarkic to start with. ${ }^{14}$ On the other hand, if a developing country were able to achieve 50 percent of the total factor productivity level of the USA, the effect would be of the order of 200-300 percent of initial GDP. The mechanism through which financial liberalization enables this is not obvious, unless financial globalization results in countries becoming irrelevant for asset prices, portfolios and firm financial policies, the so-called "country irrelevance" proposition. This would presumably speed up convergence of TFP levels and not just growth rates. The other study argues that such financial globalization is limited by agency problems that arise because rulers of sovereign states and corporate insiders pursue their own objectives at the cost of outside investors. ${ }^{15}$

Table 2. Major recipients of net international resource flows

\begin{tabular}{|l|c|c|c|c|c|}
\hline \multirow{2}{*}{ Country (Year of Crisis)* } & \multicolumn{2}{|c|}{$\begin{array}{c}\text { Total net resource flows 1990- } \\
1996\end{array}$} & \multicolumn{2}{|c|}{ Share of total flows, \% } \\
\cline { 2 - 6 } & China & $\begin{array}{c}\text { Share } \\
\text { of } \begin{array}{c}1996 \text { GDP } \\
\%\end{array}\end{array}$ & Debt & FDI & $\begin{array}{c}\text { Equity } \\
\text { portfolio }\end{array}$ \\
\cline { 2 - 6 } México (1994/1995) & 234 & 29 & 29 & 67 & 3 \\
Brazil (1999) & 118 & 36 & 35 & 39 & 26 \\
Argentina (2001/2002) & 90 & 12 & 45 & 27 & 28 \\
Korea (1997) & 71 & 26 & 45 & 39 & 16 \\
Malaysia (1997) & 68 & 13 & 59 & 12 & 29 \\
Indonesia (1997) & 63 & 63 & 18 & 47 & 35 \\
Thailand (1997) & 55 & 24 & 50 & 35 & 13 \\
India & 52 & 29 & 58 & 27 & 13 \\
Russia (1998) & 43 & 11 & 46 & 16 & 30 \\
Poland & 32 & 8 & 57 & 16 & 7 \\
Chile & 26 & 20 & 6 & 49 & 4 \\
Turkey (2000/2001) & 25 & 37 & 29 & 56 & 13 \\
Hungary & 22 & 12 & 49 & 23 & 11 \\
\hline
\end{tabular}

* Year(s) of macroeconomic crisis are indicated in brackets.

Source: World Bank (2005).

Lastly, there is a high correlation among the major country recipients of capital flows during the 1990s and the occurrence of crises, as seen in Table 2.

\section{Crisis Literature: Three Generations and Counting}

There is a close link between the actual unfolding of macroeconomic crises with their growing complexity and the theoretical literature, leading so far to three generations of crisis models. These are described in Box 3.

\footnotetext{
${ }^{14}$ Gourinchas and Jeanne (2004) develop a simulation model to calculate the benefits from financial liberalization to a developing country in a neoclassical setting.

${ }^{15}$ Stulz (2005).
} 
The first generation model attributes balance of payments crises to budget deficits financed by domestic credit in a fixed exchange rate regime with perfect capital mobility. This leads to current account deficits and a steady loss of reserves at a rate equal to the pace of credit creation; but a speculative attack resulting in a discrete exhaustion of remaining reserves occurs before these would have been used up based on credit expansion alone. A float will then be forced. Such macroeconomic overexpansion and overvaluation were the standard diagnoses of balance of payments crises in developing countries before 1993, and were the basis of most adjustment programs administered by the International Monetary Fund. The international debt crisis of the 1980s is an example.

The second generation argues that there are "crisis" and "no-crisis" multiple equilibria consistent with unchanged fundamentals. This approach was inspired the European Exchange Rate Mechanism (ERM) crises of 1992--93. The speculative attack on France in 1993 was puzzling, because the government had over the preceding years succeeded in attaining a level of macroeconomic discipline comparable to that of Germany, its partner in the ERM. Moreover, after the bands were widened, the crisis passed without a substantial further depreciation of the franc, even though there had been no tightening of macroeconomic policy in the meantime. How then could the fundamentals have been responsible for the earlier speculative pressure? The second generation argument is most simply illustrated by a "prisoners' dilemma." Consider two speculators. Each realizes that if the other sells, the resulting depreciation will reduce the value of his holdings of domestic currency. Neither wants to stand pat if the other might sell. One equilibrium is for both to sell, even though the economy may be worse off after the devaluation.

The third generation model was developed as an explanation of the East Asian crisis of 1997-98, where expansionary macroeconomic policy was not the problem, but a different kind of weakness in fundamentals appeared: structural distortions in the financial system combined with implicit exchange rate guarantees. Well-connected banks and businessmen are able to borrow in foreign currency to finance risky projects, including those in the non-traded sector such as real estate development or construction of new factories in the already-glutted steel industry. They are aware of the risk, but reasonably confident they will be bailed out by the government if things go badly. The timing of the attack again stems from the calculations of speculators who worry that if they wait too long, there will not be enough foreign exchange reserves to go around. But there is a key difference from the first generation model, where reserves fall in the run-up to crisis. In this case, liabilities artificially encouraged by moral hazard rise to a point at which investors suddenly cash in their investments, fearful that if they wait any longer, they might not be able to get their money out. The speculative attack forces the central bank to abandon the exchange rate.

Source: Frankel and Wei (2004).

The models have three implications for MACs:

- First, it is difficult to predict exactly when and, equally importantly, why the next crisis will occur and what shape it will assume. For example, the Lawson Doctrine posited that private external debt did not pose the same threat that public external debt did, presumably on the assumption that private-to-private flows would be better monitored and used. But this doctrine was proved wrong by the East Asian crisis of 1997-98. Similarly, how crises will be resolved is not clear. The comprehensive Brady Plan response to the 1980s debt crisis has given way to an ad hoc country-by-country approach.

- Second, crises of the first and third generations, which might be regarded as the most pertinent for (non-G-7) MACs, have highlighted the importance of the government's intertemporal budget constraint. While the 1980s debt crisis, Russia 1998 and Argentina 2001 all involved overtly expansionary macroeconomic policies and/or explicitly unsustainable public debt dynamics, the East Asian crisis involved large fiscal costs associated with financial sector bailouts. These were contingent liabilities which became actual liabilities once the implicitly fixed exchange rate pegs were abandoned, leading to 
distress in the enterprise and financial sectors as a result of their balance sheet currency mismatches. Thus, it is not enough to look at fiscal deficits and explicit public debt dynamics (which were benign in the East Asian countries). Contingent liabilities are also a factor.

- Third, in view of the disappointing experience with capital flows, external debt and public debt over the 1980s and 1990s, economists might be forgiven for being suspicious-not because debt is bad, but because either MACs do not seem equipped to use it well, and/or the international capital market is “unforgiving”, to borrow Guillermo Calvo's expression. The literature has turned to a discussion of why debt and capital flows make countries vulnerable. These include debt intolerance and original sin, which are discussed in section 2.3 below.

\subsection{Public Debt and Economic Growth}

We invoke results from cross-country empirical work in three areas: macroeconomic factors in growth, volatility and growth, and debt and volatility. The problems encountered in such work are well-known: how to control for country-specific factors, endogeneity and omitted variables. Causality is hard to establish, and suitable instrumental variables are difficult to find. Subject to these caveats, we use results from these three areas to link public debt and growth.

The first result is that growth, $g$, is negatively related to inflation, $\pi$, and fiscal deficits,

FD:

(1) $\quad g=g(\underset{(-)}{\pi} \underset{(-)}{F D})$.

The second and third are from the volatility literature: growth is negatively affected by output volatility, $g_{\sigma}$; and further, that $g_{\sigma}$ can be decomposed into a crisis component, i.e., deep recessions, and one that can be attributed to normal cyclical fluctuations:

$$
\begin{aligned}
& g=f \underset{(-)}{\left(g_{\sigma}\right)} ; \\
& g_{\sigma}=g_{\sigma, \text { crisis }}+g_{\sigma, \text { normal }} .
\end{aligned}
$$

The motivation for (3), as we shall see below, is that most of the damage to growth comes from the crisis component of volatility. The last result is from the debt literature, which says that the optimal debt-to-GDP ratio (from the perspective of consumption smoothing) increases with volatility but goes down with sovereign risk, which itself rises with volatility, leading to an ambiguous link between debt and volatility:

$$
d^{*}=d\left(\underset{(+)}{g_{\sigma}}, \underset{(-)}{S R}\left(g_{\sigma}\right)\right)
$$

where $d^{*}$ stands for optimal debt and SR for sovereign (or default) risk.

A simple way of thinking about the link between public debt and growth is that once the debt-to-GDP ratio crosses a (country-specific) threshold, it increases the chances of a crisis and enhances volatility, lowering growth. Alternatively, the higher fiscal deficits are, and the more volatile output is (implying lower growth), the higher is the actual public debt-to-GDP ratio likely to be (for given inflation targets) and the lower the sustainable level of debt. Each of these areas is now discussed.

The macroeconomic literature argues that stability is good for growth. Fischer (1993, p. 487) notes that the "macroeconomic framework can be described as stable when inflation is low and predictable, real interest rates are appropriate, fiscal policy is stable and sustainable, the real exchange rate is competitive and predictable and the balance of payments is perceived as viable”. 
His paper focused on three variables: inflation, fiscal deficits and the black market premium on foreign exchange, and their effects on growth in a cross-country study covering the period 196088. One finding was that a "stable macroeconomic environment, meaning a reasonably low rate of inflation and a small budget deficit, is conducive to sustained growth" (italics added). On causality, Fischer concluded that the weight of evidence pointed to a flow from high inflation to low growth, rather than vice versa. However, he also noted that low inflation is not necessary for growth, although high inflation is not consistent with sustained growth. ${ }^{16}$

Abstracting from the econometric problems, one may summarize Fischer's main result as in equation (1) above. ${ }^{17}$ The channels through which inflation reduces growth, identified in Fischer (1993), include reduced investment as well as a reduced rate of productivity growth, while larger budget surpluses are associated with more rapid growth through greater capital accumulation and greater productivity growth. Interestingly, "debt dynamics" is mentioned only once, though crucially, in Fischer (1993), while noting that a high deficit may be consistent with low inflation for a while; but that a more detailed assessment of debt dynamics may be needed to see if the deficit is sustainable and therefore consistent with macroeconomic stability. This brings in the government's intertemporal budget constraint (GIBC), which pulls together the fiscal deficit (primary fiscal balances and interest payments), inflation (seigniorage) and growth. It also properly measured pulls in contingent liabilities associated with state enterprise losses, borrowing guarantees and poor supervision of banks, in short, the potential impact of soft budget constraints for banks and enterprises. Box 4 illustrates these linkages with the stabilization experiences of Poland and Russia during the 1990s.

\section{Box 4: Poland and Russia: Contrasting Stabilizations}

Poland successfully stabilized between 1990 and 1999. It initially used the nominal exchange rate as an anchor for the price level but abandoned its fixed peg with the dollar after 17months when competitiveness became an issue. Rapid inflation reduction was never an obsession; it took eight years to attain single-digit inflation. Instead, the focus was on reducing the fiscal deficit and hardening enterprise budget constraints while maintaining a competitive real exchange rate. Growth rates increased and, aided by the resulting higher taxes and expenditure control, deficits and inflation came down gradually but credibly.

The importance of microeconomic hard budgets for growth and lasting stabilization is illustrated by the contrasting experience of Russia between 1995 and 1998. Russia succeeded in its quest for single-digit inflation by February 1998 - its exchange-rate based stabilization was launched in mid-1995; but suffered a macroeconomic crisis six months later. The issue turned out to be the "soft budgets" implicit in the "nonpayments" system, which mushroomed during the stabilization program of 1995-98. The manufacturing sector received subsidies equal to 7-10 percent of GDP, financed by a combination of government borrowing and transfers (in the form of unpaid bills) from Gazprom, the gas monopoly and RAO UES, the electricity monopoly. Trying to stabilize in this milieu required high real interest rates, which only prodded enterprises to economize even more on cash transactions and run further arrears. The government also participated in this process. More non-payments meant lower taxes and rising government debt and interest rates and hence poor growth, which fed on each other leading to the 1998 crisis.

These experiences underline that sustainable inflation reduction ultimately depends upon keeping fiscal deficits and public debt dynamics under control. This is turn depends upon adequate generation of fiscal revenues, which requires solid micro foundations for growth, namely, healthy enterprise and financial sectors based on hard budget constraints and competition.

\footnotetext{
${ }^{16}$ Other notable studies include de Gregorio (1993) and Bruno and Easterly (1998), who argued famously that once inflation crossed 40 percent per year, growth would not be sustained .

${ }^{17}$ A survey of the econometric problems may be found in Temple (2000).
} 
Output volatility is also known to exert a causally negative effect on long-run growth, an empirical result that is the basis of the volatility literature and its fundamental claim that business cycle volatility and the trend growth rate are not separate phenomena but causally linked. How is public debt linked to output volatility? One can think of two channels: macroeconomic uncertainty and its effect on investment; and the greater vulnerability to crises. A highly indebted country is more likely to experience a macroeconomic crisis in the face of a terms-of-trade shock or a reversal of capital flows, other things being equal. Such crises tend to be comprehensive, typically involving exchange rate collapses, runs on banks and sometimes, sovereign default. Deep recessions often follow. This is material because when output volatility is calculated over long periods, it averages over periods of normal cyclical fluctuation and periods of crisis. When Hnatkovska and Loayza (2004) decompose volatility into a crisis component that captures the effect of deep recessions and a component that captures normal cyclical fluctuations, crosscountry regressions over the period 1960-2000 show it is crisis volatility that truly harms long-run growth. These results place a premium on financial, fiscal, and institutional development and the avoidance of crisis as key factors in alleviating the negative impact of volatility on growth.

\subsection{MAC Debt-Help or Hindrance?}

Expressions like "debt intolerance" and "original sin" may not have found their way into the titles of recent papers on sovereign debt if the reforms of the 1980s and the liberalization of capital markets in the 1990s had led to more positive outcomes. ${ }^{18}$ The question therefore is why more positive results were not secured. The following reasons come to mind:

- Growth prospects of countries were overestimated, leading to excessive borrowing.

- Access to debt led to procrastination by governments on necessary but difficult reforms.

- Debt was misused, either facilitating capital flight or being invested in bad projects.

- Available market-based debt instruments create a predisposition to crisis.

In short, the literature tends to be negative on debt because MACs have appeared unable or unwilling to make good use of public debt, not because debt per se is bad. ${ }^{19}$ This section assesses three related questions: Whose fault is this? Will new instruments help? Are IFIs using a flawed framework for assessing how much countries should borrow?

\section{Debt Intolerance vs. Original Sin: Whose Fault is it?}

In examining the association of poor results with MAC debt, two polar views have emerged:

- "Debt intolerance" proponents argue that it is the fault of MACs themselves, especially those with a history of default and high inflation and weak fiscal and financial institutions. These countries cannot handle debt without becoming vulnerable to a crisis once external (public plus private) debt crosses 15-25 percent of GDP — a threshold much lower than actual external debt levels for big MACs. As similar arguments would apply to public debt, the policy prescription would be to lower indebtedness. Therefore, if debt is a binding constraint

\footnotetext{
${ }^{18}$ Reinhart, Rogoff and Savastano (2003), and Eichengreen, Hausmann and Panizza (2002), respectively. IMF (2003a), chapter III, also asks whether public debt in MACs is too high.

${ }^{19}$ An analogy many of us may be uncomfortably familiar with: the doctor says, "Lose weight if you want to live longer.” This doesn’t mean food is bad for us, only that we need to eat less.
} 
on growth—ruling out the possibility of "growing out of the debt problem" — countries would need to either run larger primary fiscal surpluses in the hope of lowering interest rates, or face another round of devaluation and default.

- "Original sin” proponents argue that it is not the fault of MACs, but their inability to borrow long-term in their home currency in the external markets. This creates a currency mismatch which increases output volatility and vulnerability to crisis. This mismatch would typically lead to a big increase in the debt-to-GDP ratio in the event of a real exchange rate collapse. The proponents further argue that the inability to issue long-term debt in the home currency is unrelated to domestic policies and institutions; this missing market stems instead from capital market imperfections, network externalities and transactions costs. The policy recommendation is that the IFIs and the G-10 kick-start the market by issuing debt denominated in an index of emerging market currencies and then arrange swaps with MACs to reduce or eliminate currency mismatches.

In assessing the original sin hypothesis, Goldstein and Turner (2004) agree that currency mismatches pose a threat, but disagree that they are exogenous to a particular country situation and therefore require an international solution. Their solution is to improve domestic policiessuch as adopting flexible exchange rates to create more awareness of exchange risk, and more prudent macroeconomic policies more generally — and strengthen financial institutions in order to improve domestic financial intermediation while enabling strict oversight and control of currency mismatches. There is no quick fix; a decade may be required to secure tangible and lasting improvements. The main role for the IFIs would be to monitor and report currency mismatches in their publications, and if deemed excessive, require a reduction over the medium term as a condition for IMF loans. This set of prescriptions harks back to the debt intolerance argument, although it presents a more optimistic view in that countries can overcome the mismatch and vulnerability in a reasonable time-frame.

\section{Liquidity versus Solvency: Will New Instruments Help?}

A recent report (IMF (2004)) reinforces the relative optimism of Goldstein and Turner. It lists several MAC successes in moving from high inflation and poor sovereign debt structures to debt tolerance and better debt structures (i.e., more non-indexed, long-term local currency debt) over periods of a decade or two. It identifies credible fiscal stabilization as a key prerequisite. The success stories include Chile, Israel, Mexico and Poland. The report cautions that no amount of financial engineering can substitute for sound macroeconomic policies-fiscal policy in particular-but nevertheless argues for less risky debt instruments.

One example is GDP-indexed bonds. Interest payments would be linked to real GDP growth, rising when the growth rate exceeds its trend level and vice-versa. ${ }^{20}$ The proponents identify three advantages: reduction in the volatility of debt/GDP ratios for debtor countries, less need for disruptive adjustments in the primary fiscal balance as interest payments adjust over the growth cycle, and diversification opportunities for global investors. Apart from the difficulty associated with creating a market for a new instrument which investors might find complex, other practical issues include deciding who will calculate GDP growth and dealing with the potential to manipulate it, although incentives for the latter are diminished by the observation that politicians like high growth.

${ }^{20}$ Borensztein and Mauro (2002) 
In assessing such proposals, three sets of issues arise. First, what problem is being addressed, liquidity or solvency? Krugman (1988) noted that that "There is no such thing as a pure liquidity problem; it must arise because of doubts about solvency.” It is not clear why a government which has achieved credible fiscal stabilization would want to issue GDP-indexed bonds. It could simply go to the market if it faced a temporary liquidity crunch and repay the loan when times improved. Second, for such an instrument to be effective, it would need to have a long enough maturity to take advantage of both up and down cycles. ${ }^{21}$ And third, to be credible, it might have to be issued in an up-cycle, otherwise investors might fear that governments which are happy to service the debt when interest rates are low might default when the up-cycle appears, especially if it is prolonged; they might be hard put to explain politically why they are paying such high interest rates on their debt. There are thus many issues to be considered in addition to overcoming barriers to financial innovation.

\section{Fiscal Space vs. Crowding Out: Is the IFI Macroeconomic Framework Wrong?}

The 'fiscal space' hypothesis has grown out of the position that the design of the fiscal adjustment programs in Latin American countries which suffered debt crises over the past two decades may have been self-defeating. This is because public investment programs were cut to the bone, creating infrastructure gaps that could have hurt growth and thereby compromised the attainment of debt sustainability. The idea is succinctly expressed by Calderon, Easterly and Servén (2004), page 133: “...fiscal adjustment through public infrastructure compression can be largely self-defeating in the long-run, because of its adverse effect on growth and hence on the debt-servicing capacity of the public sector". The authors fault the World Bank and IMF for focusing on short-run stabilization, fiscal deficits and gross public debt at the expense of long-run solvency defined by net debt and the government's intertemporal budget constraint.

The argument is based on the idea that while public investment in infrastructure has the immediate effect of raising the primary deficit, it also raises output and hence taxes while contributing user charges. But the most important effect stems from raising the growth rate, which could happen for example if private investment and public infrastructure investment are complements. Looking at the fiscal deficit captures only the immediate impact on the primary deficit, but focusing on the government's intertemporal budget constraint (GIBC) captures all three. The authors present evidence to show that over one third of the relative output gap between Latin America and the East Asian tigers over 1980-97 is attributable to the emergence of an infrastructure gap, though they also note that only a small part of the decline in infrastructure spending in Latin America can be associated with cuts in fiscal deficits, and that measures of infrastructure quality and efficiency are not included in arriving at this number.

While it is correct to argue for a focus on the GIBC and to warn against the presumption that private infrastructure spending will supplant public spending, there are concerns that need to be addressed. The most important are factors other than infrastructure spending which also affect the GIBC; the role played by the market in both financing government spending and acting as an arbiter of debt sustainability; and political economy considerations. Each is now discussed.

An objection one might raise is that if the GIBC (quite rightly) is to be the focus of attention, then why not examine all its facets, including revenue mobilization-a key topic in many highly indebted countries - the pricing and regulation of infrastructure services, structural

\footnotetext{
${ }^{21}$ Indeed, it is not obvious how one would fix the maturity of GDP-indexed bonds—-they might need to be designed as perpetual instruments, much like equity.
} 
reforms to promote growth, measures to promote creditworthiness, measures to restrict contingent liabilities in the financial and pension systems. Why single out infrastructure spending?

In the Easterly-Servén framework, there is no mention of the international debt markets and the role they play in determining the level of sustainable debt; sovereign (default) risk is abstracted from and the discount rate is taken as given. But if the debt market is signaling high levels of default risk, then a country may have to find a way to lower indebtedness before ramping up infrastructure spending. There are two reasons for doing this. First, taking on additional debt for new infrastructure investments when indebtedness and default risk are high leaves little room for error - but infrastructure projects are both long-gestation and risky. Second, a considerable amount of fiscal space can be created by improving creditworthiness and lowering bond spreads and interest rates, which has a direct impact on the GIBC as well as an indirect impact through private sector investment and growth. ${ }^{22}$

The alternative would be to cut current spending and preserve infrastructure spending. In assessing why this does not happen, the analysis would benefit from more attention to political economy. ${ }^{23}$ This could affect the GIBC and decisions on both spending composition and revenue in important ways. First, if politicians have a high subjective discount rate, they may prefer to preserve current primary spending at the expense of infrastructure, notwithstanding the long-term harmful consequences for the GIBC. They may also prefer to cut infrastructure spending than raise taxes or user charges. Second, as Easterly and Servén note, the cash return on infrastructure investments must exceed the discount rate for government net worth to go up. The corollary is that cuts in infrastructure spending will actually strengthen solvency if this condition is violated. While it is correct that "..fiscal policy can be designed to capture a share of the high social returns to infrastructure spending”,24, in practice infrastructure services may be mispriced, e.g., by providing free power for farmers and cross-subsidizing households while charging enterprises high prices. Third, politics may result in the selection of innately poor projects. The authors reason correctly that "It would be far better to cut just the white elephants.... while preserving the productive new construction and maintenance projects..." But politicians may not care about economic efficiency, resulting in waste which must first be eliminated before increasing infrastructure spending. This brings us to political considerations.

\section{Political Economy Explanations of Sovereign Borrowing}

The fact that MACs experience debt crises in which solvency considerations play an important role suggest that governments are overborrowing, or violating their GIBC. Since this is not economically rational, one has to look for other explanations. Governments might borrow to postpone difficult reforms, or to promote the interests of well-connected insiders, or avoid making an immediately painful but eventually beneficial adjustment to an adverse shock. Rodrik (1999) argues that the interactions between policies, shocks and conflict management institutions play a key role in explaining debt accumulation and macroeconomic performance, emphasizing that the tendency to avoid short-run adjustment costs might have prolonged negative consequences for future growth and equity. By-and-large, governments find it difficult to adjust,

\footnotetext{
${ }^{22}$ If a country's gross public debt is 80 percent of GDP, lowering spreads by 300 basis points will save 2.4 percent of GDP in interest payments.

${ }^{23}$ While the authors discuss various tricks for window-dressing the public finances, there is no guarantee (as the authors seem to imply) that adopting a framework based on the GIBC will diminish the appetite for camouflaging accounts, bad fiscal decisions and opacity.

${ }^{24}$ Easterly and Servén (2004): page 3.
} 
with procrastination fueling debt accumulation. Box 5 summarizes the main ideas underlying political economy explanations of debt dynamics.

\section{Box 5. Political Economy and Overborrowing}

The tendency to overborrow and its sequel of financial, currency and debt crises beg the question of why these costly events ever take place. The political economy approach highlights factors which lead to procrastination on difficult reforms, borrowing during delays caused by conflict on who will bear the costs of reform, and the myopic tendency to spend and borrow more in good times as a result of decision horizons linked to the chances of success in the next election instead of the long-run welfare of society. The following is a summary of the main ideas:

- Inadequate debt management and "benign neglect". Ideology, lack of technical skills, human error or inadequate information all result in problems not being promptly addressed. Learning should help, but the recurrence of crises casts doubt on this view. Overborrowing may also result from "benign neglect”, when uncertainty about reform outcomes and the possibility that things may improve spontaneously lead policy maker to procrastinate on painful adjustments.

- Conflicts among competing interest groups and strategic role of debt. The "war-of-attrition" viewpoint argues that competing groups struggle over how to apportion the burden of fiscal stabilization. The group that gives in first pays more. So both groups hold out, precipitating a larger crisis later on. These delays may be so costly that anticipating a crisis and implementing reforms right away may be better, but often only with the wisdom of hindsight. Related studies explore the impact of such conflict over time depending on which group is in power. Since groups differ in their preferences about the composition and level of government spending, current policymakers might deliberately constrain the future government by issuing excessive debt today, especially if they consider their chances of re-election slim. Such behavior is intensified by political polarization. The literature concludes that economic instability is interlinked with political instability, with the two likely to reinforce each other.

- Populist strategies. This strand attributes inefficient outcomes to income distribution and the role of median voter, whose preferences determine election outcomes and hence public policies in democracies. The would-be winners from policy reform may be uncertain of the gains, and therefore not support it. High and low income groups may form tacit coalitions favoring the accumulation of external debt, the former because they can avoid paying through capital flight and the latter because they are not expected to pay anyway. As a result, the burden is borne by the middle class. This pattern, associated with the populist economic strategies discussed by Dornbusch and Edwards (1991), leads to excessive indebtedness.

- “Common access” to government resources. This strand of literature believes that different groups will prey on government resources and that cooperation will occur only after substantial deterioration of economic conditions. The literature has dubbed this the "voracity effect", which leads to overborrowing whenever financing is available.

- Perverse incentives and moral hazard. Consumption booms and procyclical fiscal policy may be the result of expectations of bailouts in the event of a crisis. Foreign aid may foster perverse incentives for rent seeking, while blunting the motivation for corrective action, since success may reduce transfers. Empirical research in this area concludes that both aid and conditionality have worked relatively poorly (e.g., Kenya or Zambia in 1980s (see Dollar and Svensson, 1998)).

- Political budget cycles. This theory was motivated by the observation that the stage of the election cycle affects fiscal policy. The incumbent government tries to "buy" votes with approaching elections by expanding spending and shifting its composition towards observable consumption expenditure and away from investment. Empirical work confirms this tendency and finds that the variation in budget cycles is driven primarily by the desire of politicians to stay in power and the associated rents.

Sources: In addition to the references cited in the box, see Talvi and Vegh (1998), Sturzenegger and Wolf (2004), based on Drazen (2000,) and references therein. 


\section{FACTORS UNDERLYING CHANGES IN MAC DEBT LEVELS}

We now discuss factors explaining movements in the public debt-to-GDP ratios of prominent MACs before answering the three questions posed at the outset. This section is based on case studies for 15 "Big MACs" for which data were available (see Budina, Fiess and others, 2004). ${ }^{25}$ These case studies document trends in domestic and external public debt; decompose the changes in debt-to-GDP ratios into components attributable to GDP growth, fiscal effort, exchange rate and interest rate fluctuations, and other factors (recognition of contingent liabilities, privatization, debt restructuring, etc); correlate debt dynamics with key economic policy changes; and extract lessons. Of particular interest are episodes during which debt ratios increased or decreased by large amounts. Table 3 provides a summary of decompositions for ten episodes of reductions in the public debt-to-GDP ratio ranging between 15 and 60 percentage points. The numbers in bold italics identify the main factors reducing the debt-to-GDP ratio. We see that:

- All episodes involve GDP growth as one of the main contributing factors

- 80 percent of the episodes involve significant primary surpluses; in only one episode, Lebanon 1991-93, were debt ratios reduced while running significant primary deficits

- 60 percent of the episodes involve real exchange rate appreciation.

While a real appreciation of the currency helps reduce the debt-to-GDP ratio especially when the share of foreign currency-denominated debt is high, this may not last if the real exchange rate becomes overvalued. Russia between mid-1995 and the meltdown of 1998 is an example. The debt-to-GDP ratio stayed roughly constant in spite of large primary deficits, zero or negative growth and high real interest rates on ruble debt. The reason was the high initial share of dollardenominated debt plus the real appreciation of the ruble during the stabilization program, which relied on fixing the nominal exchange rate. The real exchange rate became overvalued, and when it collapsed following the August 1998 crisis, the public debt-to-GDP ratio rose by a large amount (KPU (2001)). Real appreciation was also a factor in the debt-to-GDP reduction over 2000-2003; but in this case, it was an equilibrium movement as it coincided with high oil prices, rapid growth and fiscal and institutional reform.

Table 4 summarizes thirteen episodes of increases in the public debt-to-GDP ratios ranging between 20 and 130 percentage points. The numbers in bold italics identify the main factors raising the debt-to-GDP ratio. We see that:

- All episodes involve real interest or exchange rate changes or both as significant factors; more than 75 percent of the episodes involve interest rate increases, and more than 50 percent involve real exchange rate devaluations

- Over 75 percent of the episodes involve contingent liabilities or "other factors" such as financial sector bailouts, a major factor during the East Asian crisis of 1997-98 ${ }^{26}$

- In more than half the cases, the countries ran primary surpluses during these debt run-ups; only in three cases (India, Lebanon and Korea) did countries run primary deficits

- An important finding is that economic growth collapses did not play an important part in the debt-to-GDP increase episodes. ${ }^{27}$

\footnotetext{
${ }^{25}$ Argentina, Brazil, Chile, México, and Jamaica in LAC, Lebanon in MNA, India and Pakistan in SAR, Poland, Russia, and Turkey in ECA, and Indonesia, Korea, Malaysia and Philippines in EAP.

${ }^{26}$ In Table 4, "contingent liabilities" refers to those identified as such in the data. "Other factors" also includes the impact of contingent liabilities, such as bank bailouts. In Brazil and Mexico, "debt indexation" of local currency debt to the exchange rate, inflation or short-run interest rates also played a role.

${ }^{27}$ In India, Lebanon, Pakistan and Philippines, GDP growth was a significant factor dampening the increase in the debt-to-GDP ratio.
} 
Table 3 Main Factors Underlying Debt Reductions, 1990-2003

\begin{tabular}{|c|c|c|c|c|c|c|c|c|}
\hline \multirow[t]{2}{*}{ Country, Time Period } & \multirow{2}{*}{$\begin{array}{c}\text { Total } \\
\text { Change } \\
\text { (\% of GDP) }\end{array}$} & \multirow{2}{*}{$\begin{array}{c}\text { Initial } \\
\text { Level } \\
(\% \text { of GDP })\end{array}$} & \multicolumn{6}{|c|}{ Main Contributing Factors (\% of GDP) } \\
\hline & & & $\begin{array}{l}\text { Primary } \\
\text { Balance }\end{array}$ & $\begin{array}{l}\text { GDP } \\
\text { Growth }\end{array}$ & $\begin{array}{l}\text { Real Exchange } \\
\text { Rate }\end{array}$ & $\begin{array}{l}\text { Real Interest } \\
\text { Rate }\end{array}$ & Privatization & $\begin{array}{l}\text { Other } \\
\text { Factors }\end{array}$ \\
\hline Chile, 1991-1998 & -30.2 & 42.7 & -11.5 & -15.6 & & & & \\
\hline Indonesia, 2001-2003 & -22.3 & 90.3 & -8.3 & -9.5 & -4.8 & & & \\
\hline Lebanon, 1991-1993 & -48.5 & 98.4 & 15.8 & -33.4 & & -45.5 & & 18.6 \\
\hline Malaysia, 1991-1996 & -41.4 & 91.4 & -32.3 & -37.3 & & 16.5 & & 17.8 \\
\hline Mexico, 1991-1993 & -22.8 & 50.2 & -12.9 & -3.9 & -5.9 & & & \\
\hline Pakistan, 2000-2003 & -9.5 & 109.1 & -11.1 & -16.5 & & 14.8 & & \\
\hline Philippines, 1994-1997 & -25.3 & 93.5 & -22.4 & -15.1 & -7.5 & 13.0 & & 8.2 \\
\hline Poland, 1992-2000 & -42.8 & 86.7 & 2.1 & -25.5 & -9.0 & -9.5 & -11.7 & 10.8 \\
\hline Russia, 2000-2003 & -55.2 & 88.7 & -16.7 & -15.4 & -19.3 & & -6.5 & \\
\hline Turkey, 2002-2003 & -24.9 & 91.0 & -10.3 & -11.3 & -8.2 & 8.9 & & \\
\hline
\end{tabular}

Based on Budina, Fiess and others (2004) 
Table 4 Main Factors Underlying Debt Increases, 1990-2003

\begin{tabular}{|c|c|c|c|c|c|c|c|c|c|}
\hline \multirow[t]{2}{*}{ Country, Time Period } & \multirow{2}{*}{$\begin{array}{c}\text { Total } \\
\text { Change } \\
(\% \text { of GDP) }\end{array}$} & \multirow{2}{*}{$\begin{array}{c}\text { Terminal } \\
\text { Level } \\
(\% \text { of GDP) }\end{array}$} & \multicolumn{7}{|c|}{ Main Contributing Factors (\% of GDP) } \\
\hline & & & $\begin{array}{l}\text { Primary } \\
\text { Balance }\end{array}$ & $\begin{array}{l}\text { GDP } \\
\text { Growth }\end{array}$ & $\begin{array}{l}\text { Real Exchange } \\
\text { Rate }\end{array}$ & $\begin{array}{l}\text { Real Interest } \\
\text { Rate }\end{array}$ & $\begin{array}{l}\text { Contingent } \\
\text { Liabilities }\end{array}$ & $\begin{array}{l}\text { Debt } \\
\text { Indexation }\end{array}$ & $\begin{array}{l}\text { Other } \\
\text { Factors }\end{array}$ \\
\hline Argentina, 2001-2003 & 95.3 & 146.1 & & & 41.7 & 5.5 & & & 52.2 \\
\hline Brazil, 1999-2003 & 16.5 & 58.7 & -18.5 & -4.1 & & 23.7 & 6.5 & 10.8 & -7.2 \\
\hline India, 1997/98-2002/03 & 21.8 & 87.0 & 20.0 & -21.2 & & 20.0 & & & \\
\hline Indonesia, 1998-2000 & 70.8 & 94.6 & & & 8.2 & & & & 64.4 \\
\hline Jamaica, 1997/98-2003/04 & 66.8 & 144.8 & -56.4 & -6.1 & 7.2 & 51.6 & & & 70.7 \\
\hline Korea, 1997-1998 & 31.0 & 43.5 & 4.3 & & 4.8 & & & & 20.6 \\
\hline Lebanon, 1994-2003 & 128.1 & 177.9 & 39.4 & -29.9 & & 115.5 & & & \\
\hline Malaysia, 1997-2002 & 19.9 & 70.6 & -32.0 & -10.6 & 8.7 & 17.2 & 26.2 & & 10.4 \\
\hline México, 1994-1996 & 28.0 & 55.4 & -16.8 & & & 12.5 & & 10.9 & 15.7 \\
\hline Pakistan, 1996-1999 & 19.1 & 113.5 & & -10.5 & 11.6 & 12.5 & & & 5.0 \\
\hline Philippines, 1998-2002 & 20.9 & 89.1 & -5.2 & -11.9 & 12.1 & 10.3 & & & 15.9 \\
\hline Russia, 1998-1999 & 34.0 & 88.7 & & & 40.4 & & & & \\
\hline Turkey, 2000-2001 & 34.0 & 91.0 & -8.5 & & 6.4 & 20.4 & 15.4 & & \\
\hline
\end{tabular}

Based on Budina, Fiess and others (2004) 
The results in Table 3 and 4 illustrate the big swings in both directions of the debt-toGDP ratios for individual MACs, but there is an asymmetry. Debt levels rise suddenly and by large amounts following crises; achieving subsequent reductions is slow. What these tables do not show is that the timing of the fiscal adjustment, i.e., a big increase in the primary fiscal surplus, is typically forced by the crisis itself. The impact of the market is demonstrated by the large role played by the real interest rate and the real exchange rate during the debt increase episodes. These often force large knock-on costs in connection with financial sector bailouts as a result of balance sheet currency mismatches and the impact of high real interest rates. In contrast, debt reduction episodes involve growth and fiscal effort, which typically require more time to yield tangible benefits. The results are similar to those found in IMF (2003). ${ }^{28}$

With this background, the next three sections attempt answers to the questions posed at the outset: Is the world on the verge of a debt crisis? Is public debt helping or hurting growth? What is being done-by developing countries and by international institutions-about this?

\section{WHAT IS THE LIKELIHOOD OF ANOTHER 1980s-TYPE DEBT CRISIS?}

What are the risks of another generalized debt crisis as in 1982? Our answer is "Such risks have receded since the late 1990s, but this doesn't mean that such a crisis will not appear in the future." One would be at odds with history for saying otherwise-as noted in Easterly, Islam and Stiglitz (2000), “Crises have been a constant of market capitalism...”, including not just financial shocks, but also wars, pestilence and natural disasters. One might also add that crises rarely tend to be similar — witness the successive generations of crisis models-making them difficult to predict.

Nevertheless, some guidance may be extracted from recent financial contagion episodes. Kaminsky, Reinhart and Vegh (2003) [KRV] compare cases where an exchange rate collapse or sovereign default in one country led to immediate and widespread cross-border contagion with cases where this did not happen. They conclude that the first set of cases is distinguished by three key factors: (i) a rapid build up of capital flows in the period preceding the currency collapse or default announcement (this is an obvious pre-requisite for a sudden stop); (ii) a surprise announcement of a float or default; (iii) presence of a common leveraged creditor.

These three factors certainly applied to the 1982 crisis, where petrodollars were recycled by the money center banks to MACs, those in Latin America in particular. The surprise announcement was the Mexican default in August 1982. The affected countries were hurt by commodity price declines and a big rise in US interest rates over 1980-85. The US banks, which were heavily exposed to Mexico, withdrew from emerging markets, and with the exception of Chile, Colombia and Costa Rica, all the Latin American countries defaulted. The wave of crises in MACs after Thailand announced the flotation of the baht in July 1997 was also preceded by substantial capital flows into the affected countries, as shown in Table 2. The common external shock identified by KRV was the large depreciation of the yen against the dollar, to which most of the East Asian currencies were pegged, between April 1995 and April 1997. Japanese banks retreated from East Asia; the Korean crisis prompted European banks to do so as well. Likewise, the Russian default and devaluation of August 17, 1998, led to ripple effects in Brazil and eventually in Argentina, and possibly Turkey. The Russian crisis precipitated the bailout of Long-Term Capital Management (LTCM), a heavily leveraged hedge fund with systemic links to

\footnotetext{
${ }^{28}$ IMF (2003a), Chapter III, notes: “The rise (in public debt in MACs since the mid-1990s) appears to be largely accounted for by interest and exchange rate movements and the recognition of off-balance-sheet and contingent liabilities...”
} 
large banks. ${ }^{29}$ KRV then argue that the Brazilian devaluation of January 1999, the Turkish crisis of late 2000 and its float of the lira in February 2001, and the Argentine meltdown and default of 2001 did not have widespread repercussions because these crises were widely anticipated, the asset bubble had been pricked earlier and the common creditor was therefore less leveraged.

In addition to the three factors in KRV, the crises of the 1990s have highlighted two more. The first is to do with the government's intertemporal budget constraint. The second is to with balance sheet mismatches among banks and enterprises, which has been an amplifying factor. Regarding the first, it is difficult to think of a crisis among MACs in the last two decades which has not involved the GIBC either ex ante or at ex post. Argentina and Russia have been at one extreme with adverse public debt dynamics in the lead up to the crisis in the context of a fixed exchange rate, while in the East Asian case, the big fiscal impact came ex post from the bail out of financial sector institutions. In the case of Russia, financial sector linkages with the real sector were small, as were balance sheet currency and maturity mismatches compared to those in East Asia and Argentina. Argentina's situation was further complicated by the transition costs of its pension reform. These raised fiscal deficits at a time of considerable vulnerability stemming from financial sector fragility and an overvalued real exchange rate that was difficult to address because of the hard peg to the dollar. ${ }^{30}$

The point going forward is that even if the next crisis assumes a completely unexpected shape, it would in some way affect the GIBC_-even though the manner may be subtle, for example, as a result of hidden liabilities as opposed to visibly large primary deficits and a large interest rate-growth rate differential; and have an adverse impact on the real and financial sectors; there is not much else a crisis can do. It is therefore heartening that countries are taking steps to address key sources of vulnerability, including running larger primary fiscal surpluses, building up foreign exchange reserves and shifting towards domestic currency debt. Some of these issues are discussed in more detail below for countries which went through a serious crisis in the 1980s or 1990s or both. Three questions are addressed: (i) Are public debt levels sustainable? (ii) What are countries doing to lower vulnerability? and (iii) What does the market say?

\subsection{Are MAC Public Debt Levels Sustainable?}

Public debt-to-GDP ratios for the major MACs rose significantly after the mid-1990s. The experience of the East Asian countries, Korea, Indonesia, Malaysia and Thailand, suggest that this alone does not mean that debt levels are unsustainable. Table 5 shows the abrupt and sizable jump in public debt in these countries following the 1997-98 crisis, mainly as a result of issuing government bonds to recapitalize banks. Subsequently, net foreign assets have been built up and international liquidity considerably strengthened, with the ratio of short-term external debt to reserves falling much below one. All the economies have been growing for the last five years and in most cases the expectation is that in coming years they will achieve growth of 5 percent a year or more. All have been addressing the structural distortions in the corporate and financial sectors, which, combined with implicit exchange rate guarantees and the bailouts of wellconnected business groups, led to the crisis in the first place. A reasonable assertion is that if a similar crisis recurs, public debt might well be pushed to unsustainable levels; the institutional and structural reforms being undertaken seek to prevent such an eventuality. In contrast, the Philippines also experienced rising public debt, not because of bank recapitalization, but because

\footnotetext{
${ }^{29}$ For a discussion of the bail out of LTCM, see Rubin and Weisberg (2003), pp. 284-288.

${ }^{30}$ Perry and Serven (2003) attribute much of the observed deterioration in the Argentine fiscal accounts over 1994-2001 to the widening of the social security system’s deficit following pension reforms in 1994.
} 
of rising off-budget liabilities and an increase in the fiscal deficit due to a falloff in tax revenues. Here, fiscal consolidation is a clear priority.

Table 5. Key Macroeconomic Variables in the East Asian Crisis Countries, 1996-2002

\begin{tabular}{lcccccccccc}
\hline & \multicolumn{3}{c}{$\begin{array}{c}\text { Total Public Debt } \\
\text { \% of GDP }\end{array}$} & \multicolumn{4}{c}{$\begin{array}{c}\text { Net Foreign Assets } \\
\text { \% of GDP }\end{array}$} & \multicolumn{2}{c}{$\begin{array}{c}\text { Short-term External Debt } \\
\text { \% of Reserves }\end{array}$} \\
\hline & $1995-1997$ & 1998 & 2002 & $1995-1997$ & 1998 & 2002 & $1995-1997$ & 1998 & 2002 \\
\hline & 12.8 & 43.0 & 42.4 & 4.6 & 10.4 & 19.4 & 200.7 & 54.1 & $34.13^{1}$ \\
Korea & 46.7 & 57.2 & 62.8 & 20.0 & 30.2 & 35.4 & 47.8 & 33.1 & 24.46 \\
Malaysia & 34.5 & 94.0 & 91.3 & 9.5 & 11.8 & 15.2 & 188.1 & 88.6 & 75.26 \\
Indonesia & 21.2 & 57.7 & 45.3 & -3.5 & 1.5 & 31.1 & 131.2 & 102.9 & 31.33 \\
\hline
\end{tabular}

1/ Number for 2002 is not available, 2001 used instead

Notes: Net foreign assets are the sum of foreign assets held by monetary authorities and deposit money banks, less their foreign liabilities. Short-term external debt is debt that has an original maturity of one year or less. Reserves are total reserves minus gold

Source: Staff estimates, Global Development Finance, various issues.

In addition to the level of debt, the dynamics, as determined by the interactions among the primary fiscal balances, real interest rates and real growth rates, also matter. Apart from the East Asian countries, the other prominent crisis countries of the mid-1990s — which also experienced an increase in debt by the end of the decade-were all engaged in a stabilization program. This list includes Argentina, Brazil, Russia and Turkey.

In all four cases, the nominal exchange rate served as the anchor, and the real exchange rate became overvalued. In varying degree, these countries faced similar situations. By pegging their exchange rates in the presence of open capital accounts in order to bring inflation down from high levels, these countries were subject to the macroeconomic policy 'trilemma', ${ }^{31}$ and opted to choose the first two of the following three goals: (i) use exchange rate as an instrument for price stability; (ii) keep capital account open for efficiency and flexibility; and (iii) pursue an activist monetary (interest rate) policy. But they were also subject at some point during the 1990s to the problem of unsustainable public debt dynamics and a sudden stop in capital flows- creating an impossible 'quadrilemma'. Fiscal reforms were incomplete or not credible or else fiscal policy was procyclical, as in Argentina. In such circumstances, enterprises might prefer to borrow offshore in view of pegged exchange rates combined with domestic interest rates exceeding foreign interest rates. If they are in the non-traded sector, e.g., real estate, this creates a currency mismatch and a potential vulnerability. If the size of this mismatch grows sufficiently large, borrowers might come to expect that losses would be nationalized should the exchange rate peg be abandoned, thus creating a moral hazard problem.

The preceding configuration created an exposure to a 'sudden stop' in capital flows, forcing the countries to raise interest rates in order to keep domestic currency government debt attractive. This worsened debt dynamics, with balance sheet mismatches reducing policy options further, as devaluation would trigger bankruptcies in the financial and corporate sector. Once

\footnotetext{
${ }^{31}$ The trilemma, first articulated by Obstfeld and Taylor (1998), asserts that an open economy can choose
} only two out of the three goals listed in the text. 
countries get into this kind of situation, there seem to be only two ways out: restructure debt to lower its present value, as Argentina has been attempting to do; or adopt flexible exchange rates and run exceptionally large primary fiscal surpluses as Brazil and Turkey have been doing over the past few years.

Table 6. Economic Indicators Before and After Crisis in Four Big MACs

\begin{tabular}{lccccccccc}
\hline & \multicolumn{2}{c}{$\begin{array}{c}\text { Primary Surplus } \\
\text { \% of GDP }\end{array}$} & \multicolumn{2}{c}{$\begin{array}{c}\text { Interest Payment } \\
\text { \% of GDP }\end{array}$} & \multicolumn{2}{c}{$\begin{array}{c}\text { Net Resource Transfers } \\
\text { US\$ bln }\end{array}$} & \multicolumn{2}{c}{$\begin{array}{c}\text { Real Exchange Rate } \\
\text { 1st year = 100 }\end{array}$} \\
\hline & before & after & before & after & before & after & \multicolumn{2}{c|}{ before } & after \\
\hline \hline Argentina & 0.1 & 0.8 & 3.4 & 7.3 & 7.0 & -8.1 & 97.5 & 57.5 \\
Brazil & 0.5 & 3.8 & 7.0 & 8.1 & 19.4 & 4.7 & 89.2 & 54.8 \\
Russia & -3.2 & 4.6 & 5.0 & 3.8 & 6.3 & -3.6 & 111.0 & 72.4 \\
Turkey & 0.1 & 5.2 & 18.7 & 19.8 & 2.8 & -0.4 & 98.1 & 84.9 \\
\hline
\end{tabular}

Notes: 1. Real exchange rate is bilateral with respect to US\$, period average

2. Argentina: before 1998-2000, after 2001-2003; Brazil: before 1996-1999, after 2000-2003;

Russia: before 1995-1998, after 1999-2002; Turkey: GNP is used, instead; before 1998-2000, after 2001-2003.

3. Net resource transfers are calculated as a net resource flows minus interest on long-term debtand profit remittances on FDI Data are not available for 2003

Source: Staff estimates, Global Development Finance, various issues

Table 6 captures the nature of the post-crisis adjustment in these countries by presenting averages of key variables for the three years before and three years after the crisis. Apart from Argentina, primary fiscal surpluses have been significantly ramped up and interest payments have risen from already high levels, except for Russia, which successfully restructured its debt. Net resource transfers shrank significantly in all the countries after the crisis; only in the case of Russia, which elected to prepay debt when oil prices rose, and which benefited from a significant write-down on London Club debt, was this by design. The post-crisis bilateral US dollar real exchange rate has depreciated significantly; Turkey is an exception in that by the end of the "after" period, the real exchange rate had reverted to its pre-crisis level.

The key issues in Brazil and Turkey are whether international interest rates will remain low and whether the market will be convinced by these countries' persistent primary surpluses and lower their sovereign bond spreads. In Turkey, the return of the real exchange rate to its precrisis level raises a question about the sustainability of its high post-crisis growth rate, unless microeconomic efficiency and productivity have risen. Moreover, interest payments in both countries remain in excess of even the ramped-up primary surpluses, so that an overall fiscal deficit exists that needs to be financed by additional debt issue. And to the extent that primary surpluses have been achieved by cutting public investment and social spending, this could have negative consequences for long-run growth. ${ }^{32}$ It would be reasonable to assert on this basis that debt continues to be at unsustainable levels and needs to be reduced. Box 6 illustrates, with Brazil's experience, the challenges of public debt management when debt crosses thresholds deemed unsustainable by the market.

\section{Box 6. Lessons From Brazil’s Macroeconomic Adjustment 1999-2003}

Brazil's high primary surpluses since 1999, the year in which it also switched from a crawling peg to a flexible exchanger rate regime, have been both surprising and controversial; surprising because the market, judging by the default-level bond spreads in 2002, did not expect the new administration elected that year

\footnotetext{
${ }^{32}$ This is the fiscal space argument made above, and critically assumes that the cash return on infrastructure investment exceeds the marginal cost of borrowed funds; and that fiscal waste is nonexistent.
} 
to persevere with these, and controversial because of concerns about long-run growth and welfare based on 'fiscal space'. While there has been some good news in terms of rising growth and private investment in recent months, the EMBI Global spread on March 11, 2005, while much lower at 388 basis points than a year ago, is still much higher than in Chile (58 bps) and Mexico (156 bps). While it is too early assess the long-run impacts, this box summarizes key points from Brazil’s experience over 1999-2003.

Shift towards domestic debt--does it help? By end-2003, net public debt had reached 58 percent of GDP compared to 49 percent in 2000 . At the margin, new public borrowing has been largely in the domestic market: the rise in the ratio of external debt to GDP is due mainly to the large devaluations in 1999 and 2002. This shift towards domestic borrowing has not by itself helped debt sustainability because domestic debt has tended to be indexed either to short-run interest rates, the exchange rate or the price level. Thus, the proportion of nominal (unindexed) bonds fell from 60 percent in 1996 (when credibility following the successful stabilization in 1994 was high) to less than 3 percent in 2002 as a result of economic and political uncertainty.

Contingent liabilities and exchange rate losses. Domestic public debt growth has been driven not just by the fiscal deficit but also by the recognition of contingent liabilities, financial sector bailouts, the restructuring of subnational debt and indexation. Without contingent liabilities and at 1999 nominal exchange rates, net public debt to GDP would have been 37 percent instead of 58 percent in 2003 even excluding privatization. However, interest rate and exchange rate dynamics would have been much worse without the fiscal adjustment implemented in 1999.

Fiscal effort is the key. The crucial policy response has been the raising of the primary surplus, which has been at least 3 percent of GDP since 1999. The revenue ratio reached 35 percent of GDP in 2003, 10 percentage points higher than 10 years earlier. But high interest payments and the exchange rate losses on external debt have kept the fiscal deficit at least as high as 8 percent of GDP since 1999. With the shift towards domestic debt not having tangibly helped debt dynamics so far, it is safe to say that Brazil would have been in a worse situation without its fiscal effort. Of course, higher primary fiscal surpluses alone are not enough; how to increase public savings by eliminating waste and how to better align spending composition with growth objectives remain key topics.

Moral hazard. Private, non- guaranteed debt rose by US\$59 billion over 1997-98 (about 7 percent of GDP at the time) as a result of high domestic interest rates, the high fiscal deficit and a quasi-fixed exchange rate. This created a problem, especially in 2002, when the domestic political situation led to difficulties of debt rollover. However, the authorities refused to accept responsibility for servicing this debt, letting the exchange rate float and relying on private debtors and creditors to work out their own arrangements.

Fortunately, Brazilian corporates were not highly leveraged, unlike their counterparts in Asia at the time of the 1997-98 crisis. The domestic banking system also proved resilient, partly because it had undergone a major restructuring prior to the 1998-99 crisis, and there were no bankruptcies.

Principal lessons. The first lesson is that financial engineering, be it a shift towards domestic debt or indexation, is secondary to fiscal adjustment. By itself, it could even backfire, as Russia's GKO-Eurobond swap of July 1998 or Argentina's mega-swap of June 2001, showed. ${ }^{1 /}$ Second, the Brazilian experience lends support to the debt intolerance argument and weakens the original sin hypothesis discussed above in section 2.3, because if a country cannot issue even domestic debt unindexed and in long maturities in domestic currency, it would be unreasonable to expect nonresidents to hold such debt. Third, the major challenges MACs need to prepare for include dealing with domestic moral hazard and private external debt, balance sheet mismatches and contingent liabilities.

Conclusion: For MACs with debt sustainability problems and which rule out default, the government's intertemporal budget constraint is most likely to be helped by fiscal effort, flexible exchange rates (to weaken incentives for currency mismatches), and institutional reform.

1/Aizenman, Kletzer and Pinto (2005).

Based on a note contributed by Gautam Datta. 


\subsection{What Are Countries Doing to Lower Vulnerability?}

Vulnerable countries such as Brazil, Turkey and Jamaica are running primary fiscal surpluses of unprecedented magnitude - and these have persisted for lengths of time that would have been considered politically impossible only a few years ago. This "revealed policy preference" may be the outcome of a realization that debt levels are too high and are hurting development; and that repeated defaults and restructurings are too costly in a long-term development sense. But we cannot rule out the influence of the extended period of historically low international interest rates following 9/11/2001 in deciding to pursue such a course. A last factor is that the relative roles of the government and private sector have been changing in a way that might be consistent with lower public debt-to-GDP ratios.

At the same time, affected countries have raised their reserves relative to short-term external debt, thereby lowering vulnerability to shifting market sentiment. These two responses - running large primary surpluses to dampen the upward trajectory of debt, and bolstering international liquidity-reduce exposure to the mix of unsustainable debt dynamics and vanishing international liquidity that were at the heart of the crises these countries suffered during the 1990s. In addition, the widespread adoption of flexible exchange rates and more conservative macroeconomic policies are a marked departure from the fixed exchange rates and expansionary macroeconomic policies of the 1980s.

One more point is noteworthy: a shift towards domestic currency debt in many of the major countries experiencing a crisis during the 1990s, including India and Brazil. Whether or not this lowers vulnerability depends upon whether it is accompanied by actions that strengthen the government's solvency, for example, through the generation of higher primary fiscal surpluses achieved through expenditure and revenue reform as opposed to the political expedient of cutting public infrastructure investment; ${ }^{33}$ and whether or not capital account convertibility exists. Box 6 discussed this issue in the Brazilian context.

\subsection{What Does the Market Say?}

No matter the flaws of the market - and allegations of these are numerous, including myopia, greed, herding behavior and excessive risk-taking driven by moral hazard-it remains the ultimate arbiter of MAC debt destiny. Markets today are different today from the 1980s. The large money center banks have been largely replaced by emerging market bond markets. Sovereign external debt is held in diversified portfolios; moreover, even the nature of the investor base for MAC debt has changed in a way that could lead to greater stability. ${ }^{34}$ There is greater awareness of individual country fundamentals, with more information readily available.

The incentives are also different on two counts: during the 1980s, at the political level, the fears of a systemic international financial crisis-because of the concentration of the debt in a few large money center banks_-played a decisive role in galvanizing high-level support in the creditor countries for a resolution. ${ }^{35}$ In spite of the high-level coordination facilitated by country debts being concentrated in a few large banks under the umbrella of the Baker and Brady Plans,

\footnotetext{
${ }^{33}$ But recall the caveat that public infrastructure investment is often a money-losing proposition for political reasons.

${ }^{34}$ Global Development Finance (2005).

${ }^{35}$ The exposure of U.S. money center banks to countries restructuring debt was 215 percent of banks' capital and 260 percent of their equity at end-1982; that of UK and Canadian banks was 275 percent and 195 percent of their respective equity; Chuhan and Sturzenegger (2004).
} 
the resolution and workouts took several years. More recently, expectations that Russia or Argentina would be bailed out were proven wrong. As individual investors have incurred or will incur substantial losses, the moral hazard problem associated with expected bailouts should diminish. All this means that debt problems are likely to be addressed on a case-by-case basis, with the onus for resolution falling on the countries themselves.

A last critical consideration for MACs is how the market perceives the sustainability of their debt levels, which can be inferred from the EMBI Global spread for a particular country. ${ }^{36}$ This spread is an index of default risk relative to advanced benchmark countries, typically the USA, and is usually computed as the arithmetic difference between the yield on the MAC bond and that on a bond of comparable maturity in the benchmark country. ${ }^{37}$ In general, a lower EMBI spread can be interpreted as connoting a reduced default probability, although this is not automatically the case. This is because a lower spread can be the result, for example, of the benchmark yield's going down sharply (the case in recent years) even if the probability of default and default recovery value as assessed by the market do not change. Likewise, a drop in spreads can also occur if the benchmark yield goes down while assumed default recovery value goes up with an unchanged probability of default. ${ }^{38}$ In order to deal with this ambiguity, the figures below report spreads for selected countries which experienced a crisis during 1990s together with the corporate high-yield (“junk bond”) spread.

Figure 2 contains the EMBI global spreads for Brazil, Turkey, Chile, and developed country high-yield debt, or junk bonds, for the period 1996-2003. For much of the time, Brazil's EMBI spread was above the junk bond spread, and significantly so during crisis periods, such as during the Russian crisis and its aftermath, and the confidence crisis that erupted in May 2002 in connection with the Presidential elections. It is therefore encouraging that by the end of the period shown in Figure 2, Brazilian spreads had dropped to the level of the junk bond spread. In contrast, Turkey's EMBI spread has hovered near the junk bond spread and has been much less volatile than that of Brazil, while Chile's has been consistently lower and on a declining trend. Figure 3 shows the spreads for selected East Asian countries. While spreads for Korea, Malaysia and Thailand jumped to exceed the junk bond spread during the 1997-98 crisis period, these dropped to substantially lower levels by mid-1999 and have been on a downtrend since. The Philippines is an exception. Its spread is close to the junk bond spread. Overall, therefore, the picture on spreads is mixed. Chile, Korea, Malaysia and Thailand have clearly strengthened creditworthiness, but Brazil, Turkey and the Philippines are vulnerable, although the trends for Brazil and Turkey are more encouraging.

To conclude, the initiatives being taken by indebted countries, the changed nature of the markets and incentives, and the signals embedded in EMBI spreads all suggest that the risks of a generalized debt crisis in MACs have receded since the late 1990s.

\footnotetext{
${ }^{36}$ JP Morgan’s EMBI Global is regarded as the most comprehensive MAC debt index. It was introduced in 1999. The EMBI spread is a weighted average of the spreads of US dollar bonds issued by a particular MAC. For details, see JP Morgan (1999).

${ }^{37}$ It is sometimes analytically more convenient to compute the spread geometrically. Thus, letting $s$ denote the spread, $Y$ the bond yield in the MAC and $y$ that in the benchmark country, the spread is defined implicitly by: $(1+s)(1+y)=1+Y$. However, the convention is to report the spread simply as $Y-y$.

${ }^{38}$ It is easy to construct numerical examples under risk neutrality to show this. All we observe is the price of the bond and its spread; the probability of default and implied recovery value must be extracted. A complete discussion is contained in Merrick (2004).
} 
Figure 2. EMBI Spreads for Brazil, Chile, and Turkey, 1996-2003

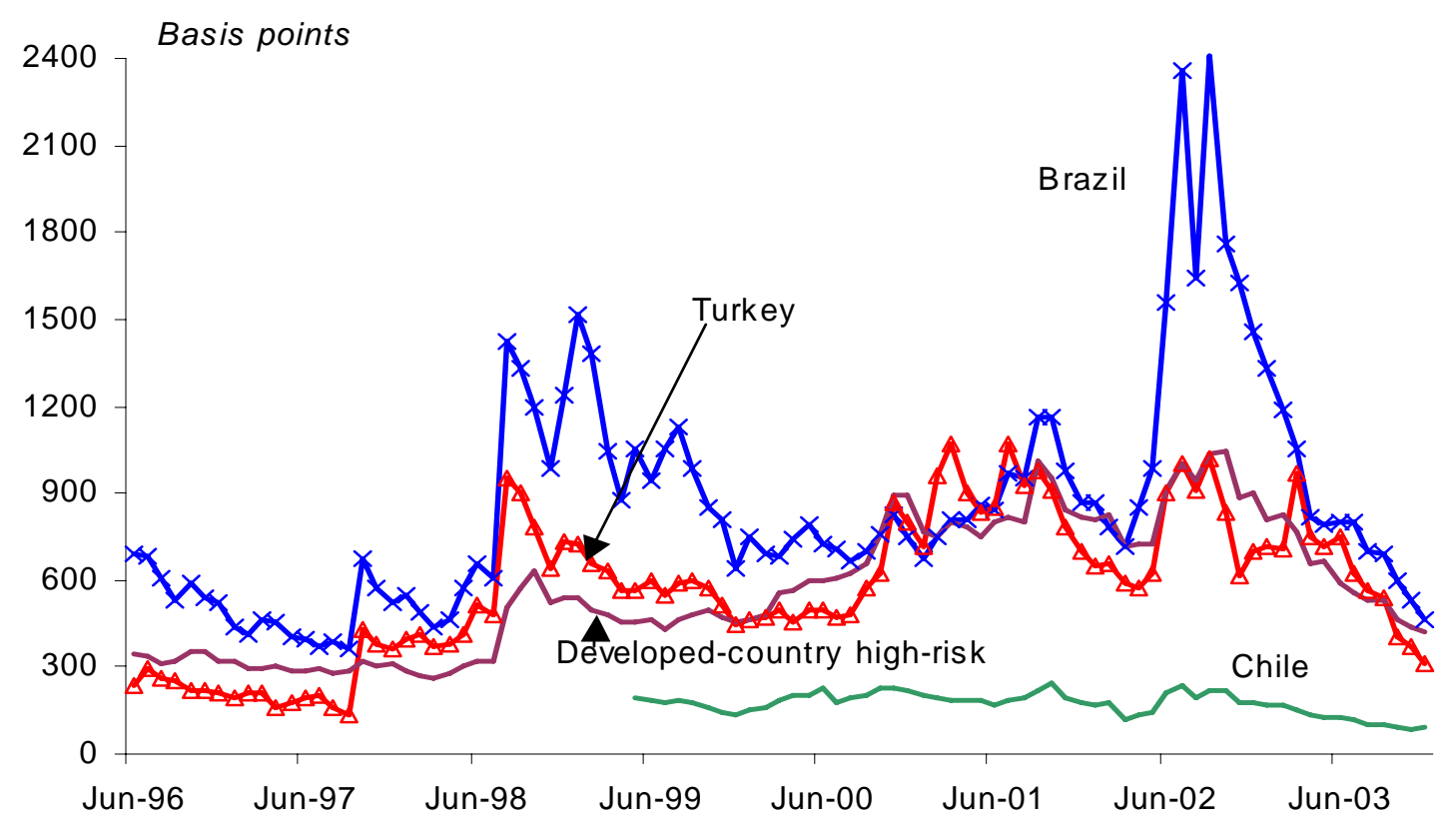

Note: Spreads on developed-country high risk is an average for the global junk bond market Sources: Bloomberg, JP Morgan Chase, and GDF, World Bank

Figure 3. EMBI Spreads for Selected East Asian Countries, 1997-2003

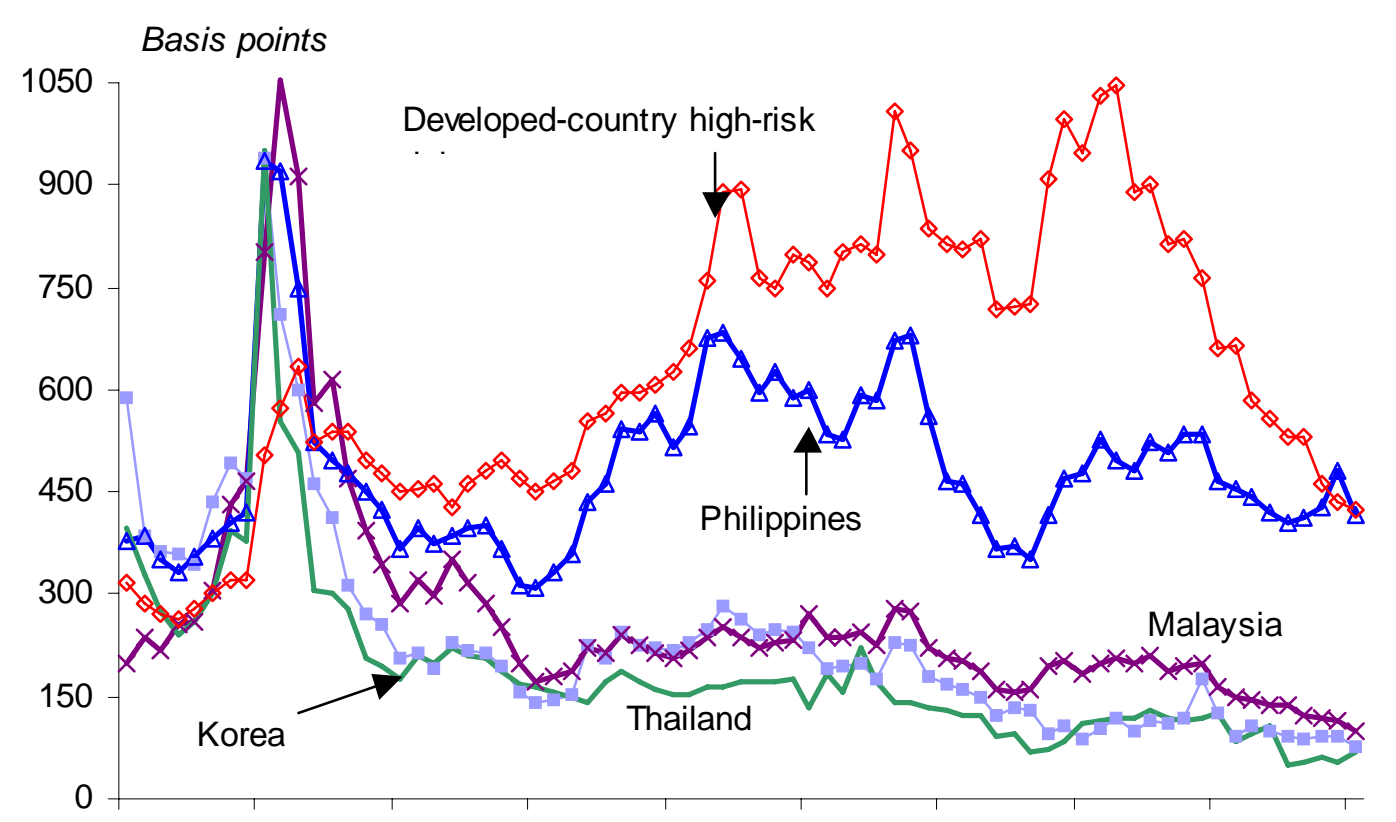

Dec-97 Aug-98 Apr-99 Dec-99 Aug-00 Apr-01 Dec-01 Aug-02 Apr-03 Dec-03

Note: Spreads on developed-country high risk is an average for the global junk bond market Sources: Bloomberg, JP Morgan Chase, and GDF, World Bank 


\section{IS PUBLIC DEBT CONSTRAINING GROWTH?}

Public debt can constrain growth in MACs (and indeed in other countries) through three channels: ${ }^{39}$

- "Debt Overhang": In a highly indebted economy, since private investors expect that future output will in effect be taxed to repay the debt, the expected return to private investment is reduced; hence investment and growth fall. ${ }^{40}$ Private investment may also be discouraged by the macroeconomic uncertainty and unpredictable taxation engendered by high debt. ${ }^{41}$ And the incentives for governments to carry out policy reform may be lower since successful reforms would result in greater pressure to repay creditors. ${ }^{42}$

- "Fiscal Space": High debt service results in pressures on the government budget and may reduce public investment and social spending, in turn reducing economic growth.

- "Crowding Out”: The financing of high fiscal deficits could raise real interest rates and dampen, or crowd out, private investment as lenders may prefer to hold relatively safe and high-yielding government paper. Where capital controls do not exist, private borrowers crowded out of the domestic market may tap the overseas market; but are unlikely to invest in real assets so long as government debt yields high returns.

Based on the evidence available, public debt appears to be constraining growth in a number of prominent MACs, most obviously in those that are experiencing debt sustainability problems. A debt sustainability problem means that the present combination of primary surpluses, real interest and growth rates is no longer tenable. It could also be a sign of solvency problems, i.e., that creditors believe that the present value of surpluses is less than the outstanding public debt. This in turn could mean that the country is not expected to grow out of its debt problem — otherwise, there would not be a sustainability issue to begin with — and generate uncertainty about future inflation and taxation with harmful effects on investment and productivity through channels similar to those discussed in the macroeconomics-growth literature in section 2.2 above. By this yardstick, public debt is constraining growth in countries like Argentina, Brazil, Jamaica, Lebanon and Turkey.

Further, any MAC which is debt intolerant and faces high spreads on its sovereign borrowing should also be regarded as being in a situation where public debt is constraining growth. MACs tend to be more volatile than their industrialized counterparts. Catão and Kapur (2004) find that once the volatility of output or the terms of trade is included in logit regressions of default probability in a cross-country panel, the credit history variable of Reinhart, Rogoff and Savastano (2003) is no longer significant. This means that credit history is to some extent a substitute for volatility, which translates into debt distress: a one percentage point increase in volatility in real GDP leads to a 12 percent decline in the sustainable debt threshold.

Paradoxically, countries that most need debt finance for smoothing are the ones that can least tolerate it. This also raises the puzzle why countries and their creditors continue to underestimate the levels of volatility, or to overestimate their own capacity to service debt in its presence.

\footnotetext{
${ }^{39}$ We rule out the trivial case where debt constrains growth in the sense that writing off debt will improve growth prospects because it ignores what was done with the debt and how this influences growth past and future compared to a situation of zero debt.

${ }^{40}$ The classic papers on the debt overhang are Krugman (1988) and Sachs (1989).

${ }^{41}$ Serven (1997).

${ }^{42}$ Corden (1989).
} 
While it is reasonable that unanticipated shocks, if severe enough, can derail development efforts in even the most fiscally responsible countries, it is harder to justify repeated episodes of debt distress. If volatility is a fact of life for many of these countries, these shocks cannot any longer be viewed as surprises; and the countries need to build up a buffer in terms of debt headroom for unanticipated shocks.

Public debt could also be a constraint to growth and development in countries like India. This claim may appear surprising in view of India's stellar growth track record and the absence of macroeconomic vulnerability. But as argued in World Bank (2003), beyond a point, public debt becomes a constraint on the composition of government spending as interest payments consume a growing fraction of revenues. It could also constrain financial sector reform and developmentbecause the government is reliant on a captive financial system to buy its debt-thereby affecting resource allocation; and reduce private investment to the extent that it exploits complementarities with public investment.

\section{Box 7. India: High Deficits, Debt and Reserves—But High Growth?}

India's growth performance during the 1980s and 1990s was exceeded by only a handful of countries; so was the size of its fiscal deficits. But it is not vulnerable to a repeat of its 1991 fiscal and balance-ofpayments (BOP) crisis because of the build up of foreign exchange reserves, capital controls, a flexible exchange rate system and widespread public ownership of banks. Nevertheless, a fiscal adjustment is needed to bolster the chances of sustained high growth over the long-run. ${ }^{1 /}$ Spending composition has deteriorated as a result of an inefficient fiscal adjustment during the ten years following the 1991 BOP crisis. Table 7 presents changes in key fiscal variables for the general government over the Eighth Plan (1992/93 to 1996/97) and Ninth Plan periods to illustrate this.

Table 7: Fiscal Adjustment Dynamics, 1985/86-2001/02 (based on period averages)

\begin{tabular}{|c|c|c|}
\hline$\%$ of $G D P$ & $\begin{array}{l}8^{\text {th }} \text { Plan }(92 / 93-96 / 97) \\
\text { versus } \\
85 / 86-89 / 90\end{array}$ & $\begin{array}{l}9^{\text {th }} \text { Plan }(97 / 98-01 / 02) \\
\text { versus } \\
8^{\text {th }} \text { Plan }\end{array}$ \\
\hline Revenues & -1.5 & -0.9 \\
\hline Primary deficit & -3.2 & +1.4 \\
\hline Debt & +8.0 & +0.0 \\
\hline Interest & +1.3 & +0.7 \\
\hline Capital expenditure & -2.8 & -0.4 \\
\hline Fiscal deficit & -1.8 & +2.1 \\
\hline
\end{tabular}

During the Eighth Plan period, revenues fell and interest payments rose relative to the pre-crisis period, 1985/86-1989/90, 'compensated' by a big reduction in capital expenditure. This happened even though growth was at its highest level over the past two decades and the primary deficit was reduced substantially. The fall in revenues and rise in interest rates both stemmed from reforms-cuts in customs and excise duty rates to stimulate efficiency, and a reduction in domestic financial repression. The net result was that capital expenditure fell by over 3 percentage points of GDP by the Ninth Plan period. And the sum of interest, administration and pensions rose by 3 percentage points of GDP and a huge 22 percentage points of revenue while developmental spending on health and education stagnated and that on irrigation, power and transport declined (not shown in table).

Crisis proofing by accumulating foreign exchange reserves and switching towards long-term rupee debt for deficit funding in this milieu meant high real interest rates for the private sector for much of the second half of the 1990s. The key to reversing the fiscal slide and eventually raising public savings to a level consistent with Tenth Plan macroeconomic targets is to mobilize revenue by completing direct and indirect 
tax reforms; and altering the composition of spending by reducing and redirecting subsidies towards rural infrastructure and agricultural R\&E-most of the poor live in rural areas. Power sector reform is also important for fiscal reasons, and to help manufacturing, the most tax-buoyant sectors in the economy.

General government grew from less than 60 percent of GDP in 1985/86 to 87 percent by 2002/03, not including debt of central public enterprises and guarantees. This risks an uncontrolled upward trajectory if interest rates rise and growth slows down. This is a good time to begin implementing a phased reform given high reserves and currently low interest rates. The Ministry of Finance's Economic Survey 2003-03 (released July 7, 2004), notes the seriousness of the situation: "Growing deficits and public debt and the concomitant declining share of the private sector in total credit have been preventing the economy from realizing its growth potential. The unobserved cost of fiscal deterioration is the growth forgone.” The challenge is to implement the Fiscal Responsibility and Budget Management Act of 2003, which mandates the central government to eliminate its revenue deficit by 2008 , i.e., raise public savings; ${ }^{2 /}$ reform the borrowing regime for states; expand center-to-state transfers linked to reform and performance; and simplify expenditure management—in short, to strengthen fiscal institutions and improve the quality of the fiscal stance.

1/ The growth rate was over 8 percent in 2003-04; but this after 4 percent growth the previous year. The trend rate of growth is closer to 6 percent-below the 8 percent target mandated for the Tenth Plan (2002-03 to 2006-07).

$2 /$ The revenue deficit is the difference between total revenues and current spending. Eliminating it is tantamount to requiring that borrowing be used only for public investment.

Source: World Bank (2003) and Pinto and Zahir (2004).

The issue of causation remains. Does high public debt cause low growth, or is it a cumulative symptom of bad past decisions on spending and taxation, misuse of fiscal resources, poorly designed stabilization programs and the postponed consequences of contingent liabilities? Omitted variables can also be an explanation, e.g., a supply shock could both lead to lower growth and a higher public debt-to-GDP ratio. And weak institutions could likewise lead to low growth and high indebtedness. ${ }^{43}$

A pragmatic view is that once a country crosses a certain debt-to-GDP threshold, debt could easily become a dominant factor going forward as well as the biggest constraint on policies and growth; how it was accumulated becomes secondary and dealing with the indebtedness itself becomes a primary task. ${ }^{44}$ And countries which choose to generate large primary surpluses in pursuit of debt tolerance can do so convincingly only if these efforts are accompanied by institutional reform, as noted in Box 8 on Turkey's reforms. The good news is that policies and institutions in MACs may mature over time; but the process is time consuming, and prone to setbacks. Some setbacks may be welfare-enhancing, forcing fundamental institutional, political and social reform. For example, Mexico in the early 1990s and Korea in the mid-1990s followed policies that turned out to be unsustainable. Both countries ended with a crisis and deep recessions, but experienced quick rebounds with output exhibiting a V-shaped path. This pattern of recovery has been facilitated by adopting greater exchange rate flexibility, relying on export orientation, and the beginning of major internal restructuring. The process has induced important political economy changes, reducing the ability of incumbents - political or business elites - to

\footnotetext{
${ }^{43}$ Acemoglu, Johnson, Robinson, and Thaichoren (2003) stress the primacy of institutions by arguing that crises are caused by bad macroeconomic policies, which increase volatility and lower growth; but bad macro policies in turn are the product of weak institutions. In order to avoid problems with endogeneity and omitted variables, they develop a technique to isolate the "historically determined component of institutions" based on the colonization strategy pursed by European settlers, and show that this is the critical factor in explaining volatility, crises, and growth.

${ }^{44}$ Fiscal dominance associated with high sovereign risk and unsustainable public debt dynamics for example becomes a severe constraint on monetary policy and the achievement of inflations targets, as argued in Blanchard (2004).
} 
block reforms. IMF (2004) gives examples of countries which are moving towards debt tolerance in spite of "bad" histories, including Chile, Israel, Mexico and Poland.

\section{Box 8. Turkey-Strengthening Institutions for Fiscal Management}

Turkey's volatile economic performance in the 1990s may be attributed in part to its coalition politics, which were compounded by weaknesses in the institutional arrangements for aggregate fiscal management. The seeming inability of a number of governments to restrain fiscal commitments within a sustainable policy framework created a credibility problem with domestic and international debt markets.

The weaknesses included (a) a non-comprehensive budget and lack of transparency in fiscal reporting, (b) fragmented responsibility and poor coordination of fiscal management among the three central agencies of government (Finance, Planning and Treasury), and (c) a failure to control and to incorporate the effect on fiscal risk of quasi-fiscal policies and guarantees which created unrecorded "hidden" liabilities, both explicit and contingent. Differences in the perspectives of coalition partners exacerbated these problems.

As a result, fiscal risk was underestimated. In 1999, the reported consolidated central government budget suggested expenditure equivalent to 36 percent of GDP, but a comprehensive assessment would have revealed general government expenditure closer to 46 percent of GDP. Including the costs of quasi-fiscal policies, such as directed credit programs, would have increased this further. For much of the period up to 1999, such costs were disguised as growing liabilities of the government to the banking sector (the socalled duty losses) that were not explicitly recognized. While estimates of these costs vary, in 1999, the public sector's financing requirement (including the costs of quasi-fiscal programs) of almost 24 percent of GDP was double the reported consolidated budget deficit of 12 percent.

The government has taken steps to address these institutional weaknesses. The Public Finance Management and Control (PFMC) Law that was passed by Parliament in December 2003 puts in place a comprehensive fiscal framework encompassing the general government. The new law sharply reduces the scope for extra-budgetary and revolving funds, which are being eliminated or integrated into the budget. Explicit appropriations are provided to compensate for "duty" obligations of state enterprises and banks and that this is now accounted for in the budget. Thus while quasi-fiscal policies still exist, their costs are now provided for in the budget. Longer term reforms that will modernize the financial control arrangements and allow greater scope for managerial authority to improve public sector performance are also being initiated.

Looking forward, the law provides for the preparation of a medium term fiscal strategy that will be endorsed by the Council of Ministers and which will inform the preparation of a medium term budget. This will start with the preparation of the 2006 budget. Defining and adhering to the medium term fiscal strategy will be key in building the credibility of government.

Box contributed by Anand Rajaram.

Box 9 summarizes recent studies which identify debt thresholds for MACs. The vast majority of MACs exceed the identified thresholds.

\section{Box 9. Debt Thresholds Identified By Recent Studies}

Three studies done at the IMF examine the difficult issue of debt thresholds:

- Based on a country's fiscal track record over 1985-2002, namely, its past ability to generate primary fiscal surpluses which are then discounted by the difference between a market-based interest rate and past average growth performance, IMF (2003, page 130) computes a sustainable level of debt for the median MAC to be 25 percent of GDP based on a sample of 21 MACs. The actual median level of public debt-to-GDP in these MACs was a huge two-and-a-half times the benchmark median level of 25 percent, indicating substantial over-borrowing. 
- Using a sample of 53 high, middle and low income countries over 1970-2001, Reinhart, Rogoff and Savastano (2003) find country-specific external debt (public plus private) thresholds in the range of 1520 percent of GDP for countries that have a history of default and high inflation.

- Pattillo, Poirson and Ricci (2004) [PPR] find that external debt (public plus private) may start exerting a negative effect on growth at levels as low as 18 percent of GDP or 65 percent of exports, based on a sample of 61 developing countries from Africa, Asia, Latin America and the Middle East over the 1969-98 period, with the sample tilted towards MACs.

The results of the three studies cited above need to be qualified. The computation of sustainable debt levels by the methodology in IMF (2003) would suggest that countries such as Brazil, which have raised primary surpluses substantially, now have higher sustainable debt levels, especially as interest rates have fallen. But the opposite is true: the increases in primary surpluses have been driven by the recognition that current debt levels are not sustainable. Likewise, "bad" histories and debt intolerance can be overcome over a decade or two, as the examples in IMF (2004) indicate. And the results in PPR could be driven by weaknesses in policies, institutions and governance, which could explain both high indebtedness and low growth; the influence of such factors is difficult to measure.

\section{WHAT IS BEING DONE ABOUT MAC PUBLIC DEBT?}

Given the evidence presented above, MACs should in general aim to permanently lower public debt-to-GDP levels in order to reduce vulnerability and create a better platform for growth. This applies to countries such as Brazil, Jamaica and Turkey, which are already committed to reducing public indebtedness by running primary surpluses of unprecedented magnitude. Even countries such as India, which are not under any imminent threat of a crisis, are concerned about the impact of public debt and spending composition on long-run growth. Even success stories like Chile, Korea and Russia are attempting to lower public indebtedness. The discussion below focuses on the two extremes: where there is a clear public debt overhang and public indebtedness is hurting growth (e.g., Brazil, Jamaica, and Turkey); and where public debt is not a constraint to growth but is being paid down nevertheless (e.g., Chile, Korea, and Thailand).

\subsection{Highly Indebted Countries}

In this group, the priority is to lower public indebtedness. To a large extent, the question of "How?" is being answered by the countries themselves: "By running large primary fiscal surpluses, and thereby signaling the country's determination not to either inflate away its debt or default in an attempt to improve creditworthiness and lower spreads." 45 Countries choosing this course have displayed remarkable political stamina and commitment. Two concerns have arisen during this process. The first is that political commitment might falter. The second is that the quality of the fiscal adjustment leaves a lot to be desired, as public investment programs have been cut to the bone, creating infrastructure gaps that could hurt growth and thereby compromise the process of attaining debt sustainability, as discussed in the section on the conceptual framework.

While both concerns are well-founded, we focus on the second one. Discussions of the possibly self-defeating form of fiscal adjustment tend to pay insufficient attention to the role of the market, politics and the quality of public investments. If the market is unforgiving as

\footnotetext{
${ }^{45}$ But, as noted above, we cannot rule out that this attitude is endogenous to the historically low interest rates since 9/11/2001.
} 
manifested in high borrowing spreads, a country has decided not to default and public infrastructure projects lose money, then cutting public investment might be the optimal way of reducing indebtedness; indeed, if public investments lose money, then these should be cut back irrespective of whether there is a debt problem or not. Efforts to create fiscal space for highreturn public infrastructure (or any other) investments thus need to consider several factors:

(a) How does the return on infrastructure investments compare with the marginal cost of borrowing? If the return on infrastructure investments is lower than the marginal cost of borrowing (which is likely to be the case for debt intolerant countries), increasing infrastructure investments could actually lower net worth. The efficiency of infrastructure service provision and its pricing become priority issues.

(b) How can governments assure a high return on new infrastructure investments without first addressing the existing portfolio? For example, the Tamil Nadu Electricity Board in India lost almost one rupee on each unit of power sold in 2001, and it sold more than 3000 million units per month. ${ }^{46}$ Can it feasibly price power differently for the marginal project without first reforming the whole power sector? If the inherited portfolio of infrastructure investments (pricing, regulation etc.) is fixed, this will increase fiscal space and net worth.

(c) Have other possibilities to enhance fiscal space been explored? Two prime alternatives are revenue mobilization, which is a prime consideration in the Philippines; and improving the composition and efficiency of non-interest current spending - a consideration that is applicable to Brazil, which has an exceptionally high revenue-to-GDP ratio.

(d) Have structural reforms to encourage growth been implemented?

\subsection{Creditworthy Yet Paying Down Public Debt}

Are countries like Chile, Korea, Russia, and Thailand making a mistake by paying down debt in spite of enjoying investment grade status? The following factors can help in trying to answer this complex question:

- What is the primary role of the state and how is it being redefined? It may be more than a coincidence that countries regarded as successful are paying off debt and self-insuring by building up net foreign assets. The government becomes the shock absorber and provider of insurance, while the private sector becomes the engine of growth. This pattern is illustrated by the experience of East Asian countries such as Indonesia, Korea, Malaysia and Thailand, in the aftermath of the 1997-98 crisis, as summed up in Table 5 above. The emphasis in these countries - and also in Chile-has shifted to policies, institutions and governance to minimize domestic moral hazard and financial sector vulnerabilities, which were at the heart of the 1997-98 crisis.

- Are there high return investment opportunities in infrastructure or the social sectors that are not being exploited? If the economic rate of return is higher than the cost of borrowing but the financial rate of return is lower, a case can be made for subsidies financed by taxes, not by borrowing. Borrowing under these circumstances would adversely affect debt dynamics.

Without knowing more about these two factors as well as the political economy and social compact in these countries, it is difficult to take a position on whether or not these countries should cease paying down public debt and building up reserves.

\footnotetext{
46 "White Paper on Tamil Nadu Government’s Finances.” Government of Tamil Nadu, 18 August 2001, page 32 .
} 


\subsection{International Development Community}

Three areas have received attention in recent years: (i) proposals on strengthening the international financial architecture (IFA); (ii) proposals on new lending instruments; and (iii) upgrading debt sustainability analysis (DSA) to better anticipate looming problems. Notwithstanding numerous initiatives, tangible progress has been limited.

On the IFA related to crisis resolution, the only proposal to take root is the inclusion of collective action clauses (CACs) in new sovereign bond issues. CACs attempt to overcome the "collective action problem" epitomized by Elliott Associates vs. Peru, and thereby speed up debt restructuring agreements in the aftermath of a crisis. ${ }^{47} \mathrm{~A}$ more ambitious attempt is contained in the proposal for a sovereign debt restructuring mechanism (SDRM), described in Box 10. It has not so far gained support among either debtor countries or their creditors.

\section{Box 10. The Sovereign Debt Restructuring Mechanism (SDRM)}

The occurrence of a number of high-profile crises since the mid-1990's (e.g. Argentina, Turkey, Russia, Indonesia, Thailand, Korea, Mexico), has reawakened the debate about an efficient resolution mechanism that would benefit both creditors and countries. The IMF proposed the SDRM in 2001 "to ensure the orderly and timely restructuring of unsustainable sovereign debts" and reach agreement with a "diffuse group of creditors...to agree collectively to a restructuring that reduces the net present value of its obligations to a manageable level”. ${ }^{1 /}$

The following benefits have been emphasized:

- The SDRM overcomes the collective action problems that contribute to delays in debt restructuring by making the decisions of a qualified majority of creditors binding on all

- It provides a more predictable and timely process compared to the current system.

At the same time, unresolved questions remain:

- Debt coverage is limited (domestic debt is excluded), which has become increasingly important throughout the 1990s

- It may not be more predictable/transparent as there will continue to be the potential for legal challenges

- If SDRM activation is left to the debtor country, the same incentives that lead to procrastination and wanting to delay admitting unsustainability (as in Argentina and Russia) would apply

- Without some automaticity, e.g., linking secondary market prices to apportioning a haircut among different creditor groups, it is not clear how the resolution will be hastened or made more transparent.

Eventually, however, the proposal will fly only if creditors and debtor countries believe it is a good idea and so far strong support has not materialized.

1/ Krueger (2002).

\footnotetext{
${ }^{47}$ The collective action problem refers to a situation where a small minority of creditors stays out of an agreement reached with the majority: they hold out in the hope of securing a better deal for themselves. Elliott Associates sued Peru for full payment on the original terms after Peru had reached an agreement with 180 creditors, obtaining a restraining order on restructured payments in the process. Rather than default on its restructured debt, Peru settled out-of-court, paying Elliott \$56 million in 2000 for unrestructured debt that had been purchased in the secondary market for \$11 million in 1996. More recently, in spite of the absence of CACs, Argentina was able to complete its restructuring of $\$ 100$ billion of bonds it had defaulted upon in December 2001 at 34 cents on the dollar when a New York court of appeals struck down the attempt of a small group of hold-out investors to scuttle the restructuring deal, which had earlier been accepted by investors holding 76 percent of the debt (Financial Times, 3 June 2005, "Argentina closes door on Dollars 100bn debt exchange", by Adam Thomson).
} 
On new instruments, two proposals that have received wide attention are GDP-indexed bonds and a proposal for overcoming "original sin", as discussed in section 2.3. Both proposals provoke the question of why such instruments have not been introduced spontaneously by the market: is it because of barriers to financial innovation, and therefore the need for the IFIs to play a catalytic role in generating a critical mass? Or is it that fundamental economic problems need to be addressed in policies, institutions and governance, which take time to address and will not be solved by such instruments? Whichever the answer, the development of such instruments is not imminent.

Another area of progress is debt sustainability analysis (DSA); but it may be difficult to develop practical approaches to key issues. These include ascertaining whether the real exchange rate is in equilibrium or not, and how to model and estimate the interactions among primary fiscal balances, real interest rates and growth. Inadequate data, especially on contingent liabilities, represents yet another impediment. A recent review of methods to incorporate uncertainty into DSA, including those being developed in the IMF, concludes that the IMF approach is likely to be the most valuable for practitioners. ${ }^{48}$

In sum, the main breakthrough so far in the field of MAC debt is at the country level. The evident willingness of some countries to address unsustainable public debt situations by reestablishing creditworthiness through fiscal effort is worth encouraging. How exactly IFIs can encourage such efforts is a matter of some debate; what should not be debated is that stronger fiscal fundamentals are a necessary condition for success; for most countries, this implies lowering public debt levels.

\section{CONCLUDING REMARKS}

The macroeconomic crises of the 1980s and 1990s have spurred concerns about sovereign debt and capital account openness. Based on a framework drawn from the growth, capital flows and crisis literature, we find that sovereign debt is constraining growth in MACs at current levels of indebtedness. However, the chances of another 1980s-type crisis have receded since the turbulence of the late 1990s. On what is being done, the willingness of countries facing debt sustainability problems to persistently run large primary fiscal surpluses stands out. Based on the relatively low thresholds for debt sustainability identified in the literature and the even lower thresholds at which public debt seems to hurt growth, this response is justified.

For MACs, a major lesson of the crises of the 1980s and 1990s is that paying attention to the government's intertemporal budget constraint (GIBC) is vital. Crises, no matter their origin in the public or private sector, tend to end up affecting the GIBC adversely. It is not enough to achieve single-digit inflation, as Russia did just six months before its 1998 meltdown; it is not enough to ensure that macroeconomic policy is conservative and that the public finances are in good order, as in Korea before 1997-98. The channels through which the GIBC gets affected are varied and not always straightforward. In addition to the standard variables - primary fiscal balances, real interest rates and growth rates - these include whether or not the enterprise and financial sectors are efficient and competitive with well-structured balance sheets; contingent liabilities, whether explicit (guaranteeing bonds issues by loss-making state enterprises) or implicit (bailing out banks even when there is no explicit deposit insurance); over-valued real exchange rates; and pension reform costs. Also included is the potential impact of exogenous shocks, when the government may be called upon to play the role of a shock absorber. Assessing

${ }^{48}$ Burnside (2004), drawing upon IMF (2002, 2003b). 
debt sustainability thus requires looking at a host of complex variables, including contingent liabilities, the micro-foundations for sustainable economic growth and the vulnerability to exogenous shocks.

If a country is experiencing public debt sustainability problems, it can safely be assumed that the impact on growth is negative-from the growth perspective, optimal debt levels are likely to be lower than sustainable debt. Moreover, the causality is more likely to flow from unsustainable public debt dynamics to low growth than vice-versa; a country with low growth potential is unlikely to attract market financing to begin with. The channels through which public debt affect growth include uncertainty about future inflation and taxation created by the debt overhang, crowding out and fiscal space problems, whereby high interest payments squeeze out public investment and social spending.

Concerns about fiscal space have led to the argument that countries which cut public infrastructure investments as part of fiscal adjustment could end up hurting the GIBC by reducing long-run growth. This argument raises at least four sets of issues: How do the economic and financial rates of return on infrastructure projects compare with the government's borrowing cost? Is there scope for reducing wastage in government spending, thereby increasing public saving, and can expenditure composition be better aligned with growth? Can the microeconomic foundation for growth be strengthened through structural reform? What are the market signals on default and devaluation risk?

There are a priori reasons to believe that countries for which the markets are signaling an unsustainable debt situation need to address this first even if the short-run impact on growth is negative. As noted above, overborrowing is more easily explained by political economy than economics; this is reinforced by the debt intolerance argument. Both political economy and debt intolerance lead to similar conclusions: that if fiscal deficits are shaped by politics and weak fiscal and financial institutions, a presumption of wasteful spending and poor public investment project selection would be reasonable. In this case, fiscal and institutional reform would need to precede any expansion of public investment spending.

A puzzling question remains: Why does the market allow overborrowing, especially by debt intolerant countries? To the extent that moral hazard fueled by expectations of an IFI bailout is a possible explanation, this is likely to have diminished after the Russian crisis of 1998 and the Argentine crisis which began in 2001. In the Russian case, only about a fourth of the IFI-led rescue package of $\$ 22.6$ billion was disbursed before being halted less than a month after being approved, notwithstanding expectations that possession of nuclear weapons implied that Russia could not be allowed to fail. Nonresident investors suffered an estimated 70 percent loss of the face value of their holdings of ruble-denominated treasury bills and bonds as a result of the devaluation and default. And the agreement reached with the London Club in August 2000 involved a 50 percent write-off in present value terms of the $\$ 31.8$ billion Russia owed. More recently, the conclusion in June 2005 of the Argentine debt restructuring deal at 34 cents on the dollar in present value terms involving \$100 billion in bonds defaulted upon in December 2001 has inflicted a loss of $\$ 67$ billion on the bondholders. ${ }^{49}$

If the experience with financial liberalization had been in line with the predictions of neoclassical growth theory, and if the experience with sovereign debt during the 1990s had been

\footnotetext{
${ }^{49}$ Financial Times, 3 June 2005, “Argentina closes door on Dollars 100bn debt exchange”, by Adam Thomson.
} 
more positive, the chances are that this paper would not have been written. But in the face of mounting evidence that capital market liberalization and access to external finance have more likely increased vulnerability than spurred growth, some hard issues arise. MACs should in general aim to lower public indebtedness. Their debt tolerance would go up with better policies, institutions and governance. But becoming debt tolerant is a time-consuming process. Can IFIs help to speed it up? For example, for countries that are developing a track record of fiscal credibility, can the IFIs help speed up the attainment of permanently lower debt-to-GDP levels by buying out private debt to lengthen maturity and lower borrowing costs? Given the magnitude of outstanding public external debt for countries like Turkey and Brazil ( $\$ 53$ billion and $\$ 60$ billion respectively, at end-2003) and already high Bank-IMF exposure levels (\$21 billion and \$28 billion respectively, see Table 8 ), such a course does not seem feasible given the current resource base of the IFIs.

Table 8. Selected Countries with Large Exposure to the IMF and World Bank, 2003

\begin{tabular}{|c|c|c|c|c|c|c|c|c|}
\hline & \multicolumn{2}{|c|}{$\begin{array}{l}\text { Outstanding Credit and Loans } \\
\text { blnUS\$ }\end{array}$} & \multicolumn{2}{|c|}{$\begin{array}{c}\text { Share in } \\
\text { Total Extemal Debt } \\
\% \\
\end{array}$} & \multicolumn{2}{|c|}{$\begin{array}{c}\text { Share in } \\
\text { Public Sector Debt } \\
\% \\
\end{array}$} & \multicolumn{2}{|c|}{$\begin{array}{c}\text { Share in } \\
\text { GDP } \\
\% \\
\end{array}$} \\
\hline & WB & IMF & WB & IMF & WB & IMF & $\mathbf{W B}$ & IMF \\
\hline Argentina & 7.92 & 10.69 & 5.61 & 11.24 & 4.17 & 8.35 & 6.09 & 12.20 \\
\hline Brazil & 8.66 & 19.06 & 4.15 & 13.46 & 2.98 & 9.66 & 1.75 & 5.67 \\
\hline Indonesia & 10.27 & 6.92 & 7.64 & 7.60 & 6.85 & 6.81 & 4.95 & 4.92 \\
\hline Russia & 6.43 & 3.25 & 3.63 & 273 & 4.24 & 3.18 & 1.42 & 1.06 \\
\hline Turkey & 5.27 & 16.06 & 3.71 & 16.64 & 3.15 & 14.15 & 2.21 & 9.92 \\
\hline Unuguay & 0.75 & 1.63 & 5.95 & 19.17 & 5.49 & 17.67 & 6.68 & 21.50 \\
\hline
\end{tabular}

Source: WBAnnual Report, 2003; IMF Finandial Statement, 2004; author's calaulations

In the absence of a fundamental shift in the thinking about market-based development finance for MACs, therefore, MACs have little option but to adjust to their market-determined external financing constraint and reduce public indebtedness through fiscal restraint and institutional reform. This general conclusion follows from the evidence pointing to low thresholds at which public debt risks becoming fiscally unsustainable and the even lower thresholds at which debt begins to harm economic growth. 


\section{References}

Acemoglu, Daron, Simon Johnson, James A. Robinson and Yunyong Thaichoren. 2003.

"Institutional causes, Macroeconomic Symptoms: Volatility, Crises and Growth.” Journal of Monetary Economics 50, 1, 49-123.

Aizenman, Joshua, Brian Pinto, and Artur Radziwill. 2004. "Sources for Financing Domestic Capital- Is Foreign saving a Viable Option for Developing Countries?” NBER Working Paper 10624, National Bureau of Economic Research.

Aizenman, Joshua. 2005. "Financial Liberalization in Latin America in the 1990s: A Reassessment.” Forthcoming, The World Economy.

Aizenman, Joshua, Kenneth M. Kletzer, and Brian Pinto. 2005. "Sargent-Wallace Meets Krugman-Flood-Garber, or: Why Sovereign Debt Swaps Don’t Avert Macroeconomic Crisis,” Economic Journal. Forthcoming.

Barro, Robert J. 1979. “On the Determination of the Public Debt,” Journal of Political Economy 87(5, part 1)”: 940-971.

Barro, Robert J. 1995. “Optimal Debt Management.” NBER Working Paper 5327.

Barro, Robert J., and Xavier Sala-I-Martin. 1995. Economic Growth. McGraw-Hill, Inc.

Blanchard, Olivier J., and Francesco Giavazzi. 2003. "Improving the SGP through a Proper Accounting of Public Investment.” Unpublished, Cambridge, Massachusetts: MIT Press.

Blanchard, Olivier. 2004. "Fiscal Dominance and Inflation Targeting. Lessons from Brazil.” Mimeo., MIT.

Borenzstein, Eduardo, and Paulo Mauro. 2002. “Reviving the Case for GDP-Indexed Bonds”, IMF Discussion Paper 02/10.

Bosworth, Barry, and Susan Collins. 1999. "Capital Flows to Developing Economies: Implications for Saving and Investment," Brookings Papers on Economic Activity, Vol. 1, pp. 143-69.

Bruno, Michael, and William Easterly. 1998. “Inflation Crises and Long-run Growth.” Journal of Monetary Economics, 3-26.

Budina, Nina and Norbert Fiess. 2004. "Public Debt and its Determinants in Market Access Countries: Results from 15 Country Case Studies.” The World Bank.

Burnside, Craig. 2004. “Assessing New Approaches to Fiscal Sustainability Analysis,” draft, World Bank.

Calderon, Cesar, William Easterly and Luis Serven. 2004. “Infrastructure Compression and Public Sector Solvency in Latin America in Easterly and Serven eds. The Macroeconomics of Infrastructure. Regional Study, Latin America and Caribbean Region, The World Bank. 
Catão, Luis, and Sandeep Kapur. 2004. "Missing Link: Volatility and the Debt Intolerance Paradox.” IMF Working Paper WP/04/51. March 2004.

Chuhan, Punam, and Federico Sturzenegger. 2004. "Default Episodes in the 1990s: What Have We Learned?” In Joshua Aizenman and Brian Pinto, editors, Managing Economic Volatility and Crises: A Practitioner's Guide. The World Bank.

Corden, W. Max. 1989. “Debt Relief and Adjustment Incentives,” in Frenkel, Jacob, Michael Dooley, and Peter Wickham (eds.) Analytical Issues in Debt, International Monetary Fund.

De Gregorio, Jose. 1993. “Inflation, Taxation and Long-Run Growth.” Journal of Monetary Economics, 31, 271-298.

Dornbusch, Rudiger W. and Sebastian Edwards. 1991. "Macroeconomic Populism in Latin America". NBER Working Paper No. W2986

Dollar, David, and Jakob Svensson. 1998. "What Explains the Success or Failure of Structural Adjustment Programs”. Economic Journal 110, 894- 917.

Drazen, Allan. 2000. Political Economy in Macroeconomics. Princeton Univ. Press, Princeton NJ.

Easterly, William, Roumeen Islam, and Joseph E. Stiglitz. 2000. "Shaken and Stirred: Explaining Growth Volatility.” In Boris Pleskovic and Joseph E. Stiglitz, eds., Annual World Bank Conference on Development Economics 2000. Washington, D.C.: World Bank.

Easterly, William, and Luis Servén (eds.). 2004. The Macroeconomics of Infrastructure. Regional Study, Latin America and Caribbean Region, The World Bank.

Eaton, Jonathan. 1993. “Sovereign Debt: A Primer.” The World Bank Economic Review, Vol. 7, No. 3, pp 137-172.

Eichengreen, Barry and Michael Mussa. 1998. Capital Account Liberalization: Theoretical and Practical Aspects. IMF Occasional Paper no. 172. Washington DC, International Monetary Fund.

Eichengreen, Barry, Ricardo Hausmann, and Ugo Panizza. 2002. Original Sin: The Pain, the Mystery, and the Road to Redemption," paper prepared for the conference "Currency and Maturity Matchmaking: Redeeming Debt from Original Sin,” IADB, Washington, DC.

Fischer, Stanley. 1993. “The Role of Macroeconomic Factors in Growth.” Journal of Monetary Economics 32, 485-512.

Frankel, Jeffrey, and Shang-Jin Wei. 2004. “Managing Macroeconomic Crises: Policy Lessons”, in Joshua Aizenman and Brian Pinto, editors, Managing Economic Volatility and Crises: A Practitioner's Guide. Cambridge University Press, forthcoming.

Goldstein, Morris, and Philip Turner. 2004. Controlling Currency Mismatches in Emerging Markets. Washington, Institute for International Economics. 
Gourinchas, Pierre-Olivier, and Olivier Jeanne. 2004. "The Elusive Gains from International Financial Integration.” IMF Working Paper March 2004. Washington DC. International Monetary Fund.

Hnatkovska, Viktoria, and Norman Loayza. 2004. "Volatility and Growth”, in Joshua Aizenman and Brian Pinto, editors, Managing Economic Volatility and Crises: A Practitioner's Guide. Cambridge University Press, forthcoming.

International Monetary Fund. 2002. “Assessing Sustainability.” Manuscript, PDR, IMF, May 28.

International Monetary Fund. 2003a. World Economic Outlook. Public Debt in Emerging Markets. September 2003.

International Monetary Fund. 2003b. "Sustainability Assessments—Review of Application and Methodological Refinements.” Manuscript, PDR, IMF, June 10.

International Monetary Fund. 2004. "Sovereign Debt Structure for Crisis Prevention.” Research Department, July 2, 2004.

Kaminsky, Graciela, L., Carmen M. Reinhart and Carlos A. Vegh. 2003. “The Unholy Trinity of Financial Contagion.” NBER Working Paper 10061. National Bureau of Economic Research, Cambridge, MA.

Kharas, Homi, Brian Pinto, and Sergei Ulatov. “An Analysis of Russia’s 1998 Meltdown: Fundamentals and Market Signals.” Brookings Papers on Economic Activity, 2001, (1), pp. 1-67.

Krugman, Paul. 1988. "Financing versus forgiving a debt overhang," Journal of Development Economics, 29, 253-268

Krueger, Anne. 2002. "New Approaches to Sovereign Debt Restructuring: An Update on Our Thinking.” Conference on "Sovereign Debt Workouts: Hopes and Hazards.” Institute for International Economics. Washington DC, April 1, 2002.

Lucas, Robert E. Jr., 1988. “On the Mechanics of Economic Development,” Journal of Monetary Economics.

Mankiw, N. Gregory, David Romer, and David N. Weil. 1992. "A Contribution to the Empirics of Economic Growth," NBER Reprints 1725.

Merrick, John. 2004. "Evaluating Price Signals from the Bond Markets,” in Joshua Aizenman and Brian Pinto, editors, Managing Economic Volatility and Crises: A Practitioner's Guide. The World Bank.

Mody, Ashoka, and A.P. Murshid. 2002. “Growing Up With Capital Flows.” IMF Working Paper WP/02/75.

Morgan, JP. 1999. "Introducing the J.P. Morgan Emerging Markets Bond Index Global (EMBI Global).” Methodology Brief, JP Morgan, New York. 
Obstfeld, Maurice, and Alan M. Taylor. 1998. "The Great Depression as a Watershed: International Capital Mobility in the Long Run,” in The Defining Moment: The Great Depression and the American Economy in the Twentieth Century, ed. by Michael D. Bordo, Claudia D. Goldin, and Eugene N. White, pp. 353-402 (Chicago: University of Chicago Press).

Patillo, Catherine, Helene Poirson, and Luca Ricci. 2004. "What are the Channels Through Which External Debt Affects Growth.” IMF Working Paper WP/04/15. January 2004.

Perry, Guillermo, and Luis Serven. 2003. "The Anatomy of a Multiple Crisis: Why was Argentina Special and What can we Learn From It?”, draft, World Bank.

Pinto, Brian, and Farah Zahir. 2004. "Why Fiscal Adjustment Now,” Economic and Political Weekly, pp. 1039-1048, March 6, 2004. India.

Reinhart, Carmen, Kenneth Rogoff, and Miguel Savastano. 2003. “Debt Intolerance.” Brookings Papers on Economic Activity 1.2003.

Rodrik, Dani. 1999. "Where Did All The Growth Go? External Shocks, Social Conflict, and Growth Collapses” Journal of Economic Growth, Vol. 4, December, pp. 358-412.

Rubin, Robert E., and Jacob Weisberg. 2003. In an Uncertain World: Tough Choices from Wall Street to Washington. Random House, New York.

Sachs, Jeffrey. 1986. "The debt overhang of developing countries,” paper presented at the Conference in memorial to Carlos Diaz-Alejandro, Helsinki, August 1986.

Serven, Luis. 1997. "Uncertainty, Instability, and Irreversible Investment: Theory, Evidence, and Lessons for Africa,” World Bank Policy Research Working Paper No. 1722.

Stulz, Rene. 2005. “The Limits of Financial Globalization.” American Finance Association presidential address, Philadelphia, January.

Sturzenegger, Federico and Holger Wolf. 2004. "Developing Country Debt: An Overview of Theory, Evidence, Options.” Draft, Economic Policy and Debt Department, PREM Anchor, The World Bank.

Talvi, Ernesto, and Carlos A. Vegh, 2000. "Tax Base Variability and Procyclical Fiscal Policy." NBER Working Paper 7499, National Bureau of Economic Research.

Temple, Jonathan. 2000. “Inflation and Growth: Stories Short and Tall.” Journal of Economic Surveys 14,4, 395-426.

World Bank. 2003. India: Sustaining Reform, Reducing Poverty. World Bank Development Policy Review, Oxford University Press, New Delhi.

World Bank. 2005. Economic Growth in the 1990s. Learning from a Decade of Reform. 
Table A. List of Market Access Countries (MACs) and Low Income Countries (LICs)

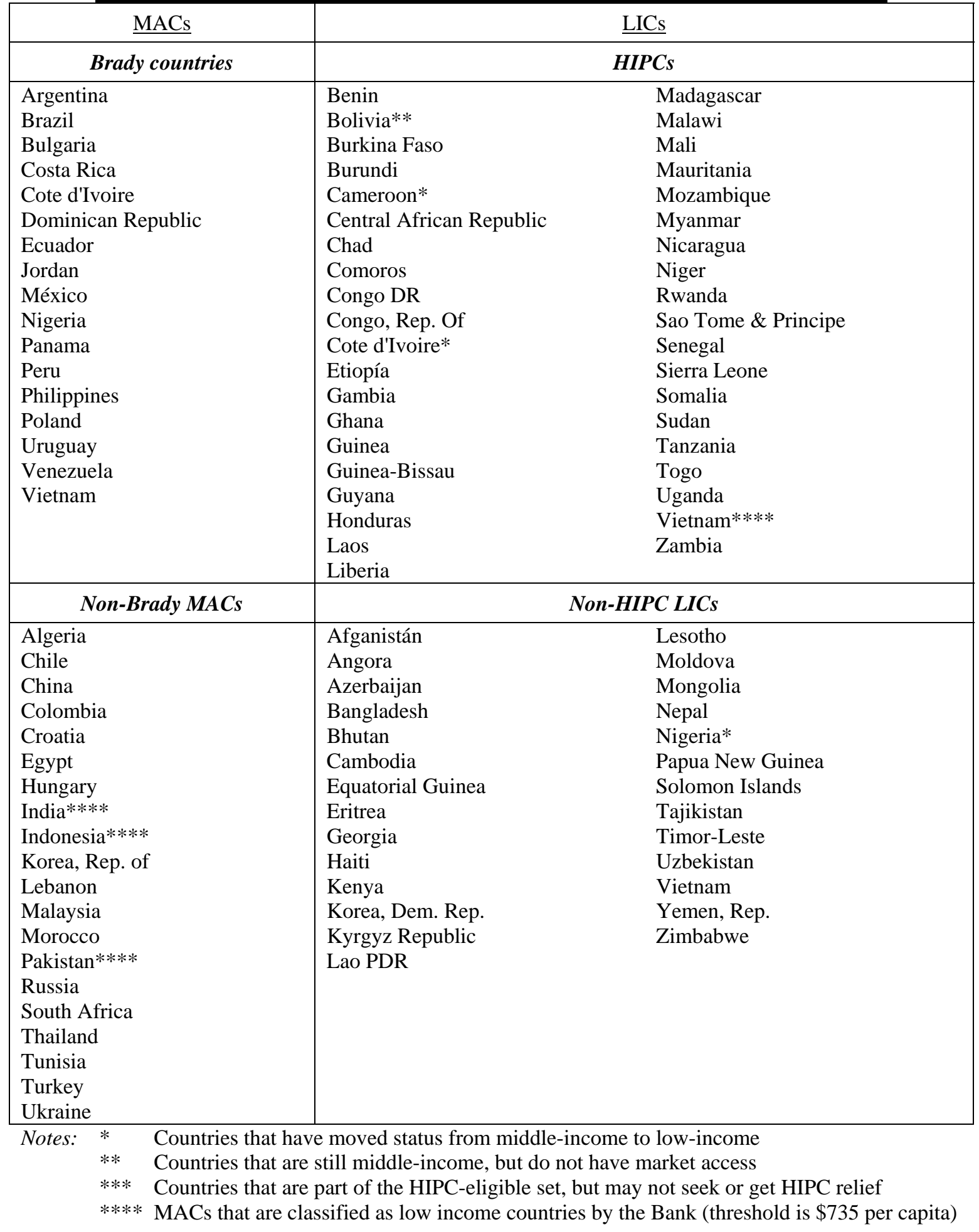

